\title{
State Attorney General Enforcement of Unfair or Deceptive Acts and Practices Laws: Emerging Concerns and Solutions
}

\author{
Cary Silverman* \& Jonathan L. Wilson**
}

\section{INTRODUCTION}

Consumer protection laws provide state attorneys general (AGs) with sweeping authority to address improper business practices. As their name suggests, most state Unfair or Deceptive Acts and Practices (UDAP) laws ${ }^{1}$ broadly prohibit any conduct that can be viewed as "unfair" or "deceptive." 2 The open-ended nature of these terms provides substantial power to state AGs. In most cases, state AGs and their staffs quietly, responsibly, and effectively apply this broad authority to protect the rights of consumers. In recent years, however, there is growing concern among businesses, courts, and commentators that some UDAP actions have strayed from their intended purpose of protecting consumers. The types of enforcement actions that have raised controversy bear little resemblance to traditional government enforcement of consumer protection laws.

This Article identifies four common elements in the types of UDAP actions that have raised concern. First, these cases are typically not sparked by consumer complaints, but are developed by private lawyers retained by AGs to pursue the litigation on the state's behalf. Second, the cases often target practices already regulated by government agencies charged with protecting the public. AGs have, for example, used UDAP laws to step into the shoes of the U.S. Food and Drug Administration to

* Cary Silverman is a partner in Shook, Hardy \& Bacon L.L.P.'s Public Policy Group. He received his B.S. from the State University of New York College at Geneseo and his J.D. and M.P.A. with honors from The George Washington University, where he serves as an adjunct law professor.

** Jonathan L. Wilson is an Of Counsel at Shook, Hardy \& Bacon L.L.P. He received his B.S., with distinction, from the University of Kansas and his J.D., cum laude, from Southern Methodist University Dedman School of Law.

1. These laws are also frequently referred to as Consumer Protection Acts (CPA) or Unfair or Deceptive Trade Practices Acts (UDTPA).

2. See, e.g., W. VA. CODE ANN. § 46A-6-104 (West 2002) ("Unfair methods of competition and unfair or deceptive acts or practices in the conduct of any trade or commerce are hereby declared unlawful.”). 
regulate the marketing of prescription drugs or impose fines that are not warranted under federal law. Third, these enforcement actions routinely seek the maximum civil penalty authorized by law, then aggregate that amount "per violation," multiplying it for each letter mailed, sales call made, prescription filled, or product or service sold. Calculating civil penalties in this manner may lead to fines that are disproportionate to the alleged misconduct or consumer loss. Finally, rather than provide a benefit to consumers, some AGs have distributed funds from the resulting settlements and judgments to outside organizations and politically popular projects with no more than an attenuated relationship to the lawsuits.

While these types of UDAP actions remain the exception, rather than the rule, they are becoming more common. They pose a threat to good government, sound public policy, and due process. To address excesses in UDAP enforcement actions, this Article offers recommendations for consideration of courts and policymakers. ${ }^{3}$ These proposals would preserve an AG's ability to quickly stop deceptive practices, obtain restitution for any consumer who suffered a loss, and impose civil penalties on those who willfully violate the law, while addressing the specific types of problematic enforcement practices documented in this Article.

\section{UNFAIR AND DECEPTIVE TRADE PRACTICE ACTS: ORIGIN AND PURPOSE}

In 1914, Congress established the Federal Trade Commission (FTC). ${ }^{4}$ The FTC consisted, as it does today, of five members appointed by the President with the advice and consent of the Senate. ${ }^{5}$ When Congress passed the FTC Act, it was concerned about the growth and spread of monopolies, so the law charged the FTC with regulating "unfair methods of competition," ${ }^{6}$ and in the beginning, the Commission focused largely on antitrust and other trade regulation violations.

After the Supreme Court found that the FTC lacked power to regulate activities that had no effect on competition between businesses,

3. Private rights of action brought under UDAP laws, which raise their own distinct set of concerns, are beyond the scope of this Article. See generally Victor E. Schwartz \& Cary Silverman, Common-Sense Construction of Consumer Protection Acts, 54 U. KAN. L. REV. 1 (2005).

4. See Federal Trade Commission Act, Pub. L. No. 63-203, 38 Stat. 717 (1914) (codified as amended at 15 U.S.C. $\S \S 41-58(2012))$.

5. See 15 U.S.C. $\S 41$ (2012).

6. See Federal Trade Commission Act, Pub. L. No. 63-203, § 5, 38 Stat. 717, 719 (1914). 
such as false advertising, ${ }^{7}$ Congress empowered the Commission to regulate consumer transactions in 1938 by amending Section 5(a)(1) of the FTC Act to declare unlawful all "unfair or deceptive acts or practices in commerce." 8 The FTC Act itself provided little guidance as to which activities were "unfair" or "deceptive," because in 1914, when Congress extensively debated the definition of "unfair," it recognized that "it would undertake an endless task" by attempting to provide an exhaustive list of prohibited practices. ${ }^{9}$ For this reason, Congress decided, by a "general declaration," to condemn "unfair" practices and "leave it to the commission to determine what practices were unfair." 10 Congress adopted this same approach when it amended the Act in 1938 to include "unfair or deceptive acts" in consumer transactions.

During the 1960s and 1970s, most states adopted UDAP laws to supplement federal consumer protection enforcement. ${ }^{11}$ Most UDAP laws were based on alternative forms suggested by the FTC ${ }^{12}$ or model state legislation developed by the National Conference of Commissioners on Uniform State Laws. ${ }^{13}$ Today, every state has a consumer protection statute. ${ }^{14}$ While these laws take various forms, most generally prohibit "unfair" and "deceptive" acts. ${ }^{15}$ Some UDAP laws include a non-

7. See FTC v. Raladam Co., 283 U.S. 643, 654 (1931) (holding the FTC lacked authority to issue cease-and-desist order to stop advertising of an ineffective weight-loss product); see also FTC v. R.F. Keppel \& Bro., Inc., 291 U.S. 304, 313 (1934) (suggesting that Congress should expand the power of the FTC to regulate unfair practices that exploit consumers); ANN. REP. OF THE FED. TRADE COMM'N at 14-15 (1935), reprinted in 6 THE LEgISLATIVE History OF THE FEDERAL ANTITRUST LAWS AND RELATED STATUTES 4836, 4836-37 (Earl W. Kintner ed., 1983) [hereinafter Kintner] (advocating for a statutory change).

8. Wheeler-Lea Act of 1938, Pub. L. No. 75-447, § 3, 52 Stat. 111 (1938) (codified as amended at 15 U.S.C. § 45(a)(1) (2012)).

9. H.R. REP. No. 63-1142, at 19 (1914) (Conf. Rep.).

10. S. REP. No. 63-597, at 13 (1914), reprinted in 5 Kintner, supra note 7, at 3900, 3909-10.

11. J.R. Franke \& D.A. Ballam, New Applications of Consumer Protection Law: Judicial Activism or Legislative Directive?, 32 SANTA ClARA L. REV. 347, 357 (1992); Jack E. Karns, State Regulation of Deceptive Trade Practices Under "Little FTC Acts": Should Federal Standards Control?, 94 DiCK. L. REV. 373, 374 (1990).

12. See Council of State Governments, Unfair Trade Practices and Consumer Protection LAW, in Suggested State Legislation C4-C5 (1969); see generally William A. Lovett, Private Actions for Deceptive Trade Practices, 23 ADMIN. L. REV. 271, 275 (1971).

13. Unif. Deceptive Trade Practices Act (amended 1966), 7A U.L.A. 139 (2002) (withdrawn from recommendation 2000).

14. See Karns, supra note 11, at 373 n.2 (citing state statutes).

15. See, e.g., AlaSKa StAT. AnN. § 45.50.471(a) (West 2007 \& Supp. 2014); Ga. Code AnN. $\S 10-1-393(a)$ (West 2003 \& Supp. 2013); Ky. ReV. StAT. AnN. § 367.170 (West 2006); LA. STAT. ANN. § 51:1405 (2003 \& Supp. 2014); MASS. GEN. LAWS ANN. ch. 93A, § 2(a) (West 2006); Mich. Comp. LAWS ANN. § 445.903 (West 2011); Miss. CodE AnN. § 75-24-5(1) (West 1999 \& Supp. 2013); Mont. Code AnN. § 30-14-103 (2013); N.C. Gen. Stat. ANN. § 75-1.1(a) (West 2012); Ohio Rev. Code Ann. § 1345.02(A) (West 2004 \& Supp. 2014); Or. Rev. Stat. Ann. § 646.608(1)(u) (West 2011 \& Supp. 2014); TeX. Bus. \& CoM. CodE ANN. § 17.46(a) (West 2011). 
exclusive list of specifically prohibitive practices, ${ }^{16}$ but like the FTC Act, they do not define the broad contours of what constitutes "unfair" and "deceptive." The terms were intentionally left as undefined so that the UDAP laws could adapt to future business practices. ${ }^{17}$

The task for defining these terms was left to state officials and the courts. Most UDAP laws provide the AG with rulemaking authority, which generally allows the AG to issue rules and regulations interpreting the law and establishing prohibited conduct. ${ }^{18}$ In determining what constitutes an "unfair" or "deceptive" act state courts are often required by their UDAP statute to look to FTC policies, orders, regulations, and rulings for guidance. This statutory deference can require the states' courts to give "consideration"19 or "due consideration and great

The District of Columbia's statute, however, does not explicitly recognize a violation of the act for "unfair" trade practices, and courts have not permitted such actions. See D.C. CODE ANN. § 28-3904 (West 2015); Atwater v. D.C. Dep’t of Consumer \& Regulatory Affairs, 566 A.2d 462, 465 (D.C. 1989).

16. See, e.g., ALASKa StAT. ANN. § 45.50.471(b) (West 2007 \& Supp. 2014); ARK. Code AnN. §§ 4-88-107(a), 88-109 (West 2004); Colo. REV. STAT. ANN. § 6-1-105(1) (West 2002 \& Supp. 2013); D.C. CODE ANN. § 28-3904(a)-(hh) (West 2015); GA. CODE ANN. § 10-1-393(b) (West 2003 \& Supp. 2013); IDAHO CoDE ANN. § 48-603 (West 2006 \& Supp. 2013); IOWA CodE ANN. § 714.16(2) (West 2003); Mich. Comp. LaWs ANN. § 445.903(1) (West 2011); MinN. STAT. ANN. § 325D.44 (West 2011); Miss. CodE ANN. § 75-24-5(2) (West 1999 \& Supp. 2013); OHIO REv. CodE AnN. § 1345.02(B) (West 2004 \& Supp. 2014); OKLA. STAT. AnN. tit. 15, § 753 (West 2013); OR. Rev. Stat. AnN. § 646.608(1) (West 2011 \& Supp. 2014); Tex. Bus. \& Com. Code AnN. § 17.46(b) (West 2011); W. VA. CoDE ANN. § 46A-6-102(7) (West Supp. 2013).

17. Glenn Kaplan \& Chris Barry Smith, Patching the Holes in the Consumer Product Safety Net: Using State Unfair Practices Law to Make Handguns and Other Consumer Goods Safer, 17 YALE J. ON REG. 253, 279-80 (2000).

18. See, e.g., Alaska Stat. AnN. § 45.50 .491 (West 2007); ConN. Gen. STAT. AnN. § $42-$ 110b (West 2012); GA. CODE ANN. § 10-1-394 (West 2003); IOWA CODE ANN. § 714.16(4)(a) (West 2003); Ky. ReV. STAT. ANN. § 15.180 (West 2010); MASS. Gen. LAWS ANN. ch. 93A, § 2(c) (West 2006) (authorizing the attorney general to make rules and regulations "interpreting the provisions" of the UDAP statute); Miss. CODE ANN. § 75-24-27(1)(f) (West 1999); N.M. STAT. ANN. § 57-12-13 (West 2003); Ohio Rev. Code AnN. § 1345.05(B)(2) (West 2004 \& Supp. 2014); UtAH Code AnN. $\S 13-2-5$ (West 2010) (authorizing rules to "administer and enforce" UDAP statute).

19. See, e.g., 815 ILl. COMP. STAT. ANN. 505/2 (West 2008). 
weight" ${ }^{20}$ while others require interpretation of state law to be "guided" 21 or be "consistent" 22 with FTC actions.

While these laws are sometimes referred to as "Little FTC Acts," there are some critical differences between UDAP laws and the FTC Act. When Congress enacted the FTC Act, it was concerned that the vagueness of the terms "unfair" and "deceptive" could lead to arbitrary and abusive lawsuits and punish businesses without prior notice that the conduct at issue was improper. Congress alleviated some of these concerns by placing the power to determine unfair practices in a nonpartisan Commission ${ }^{23}$ and by providing the FTC with sole enforcement authority. ${ }^{24}$ The FTC's broad authority to bring actions is further tempered by budgetary and staffing restraints. The FTC has to balance these restraints and prioritize those actions that best serve public interest. ${ }^{25}$ Congress also recognized that the FTC's power under the Act is "merely preventive and cooperative, rather than penal." 26 The FTC can immediately act to stop deceptive practices and seek restitution for consumers. $^{27}$ Civil penalties are reserved for situations in which the violator had "actual knowledge that such act or practice is unfair or deceptive and is unlawful," 28 and the FTC can only seek civil penalties on businesses that violate a cease-and-desist order, consent agreement, or had clear notice that conduct is prohibited. ${ }^{29}$

20. See, e.g., Ala. Code § 8-19-6 (2002); Alaska Stat. AnN. § 45.50 .545 (West 2007); Fla. Stat. ANN. § 501.204(2) (West 2010); IdAHo Code ANN. § 48-604 (West 2006); Md. CodE ANN., CoM. LAW § 13-105 (West 2013); MonT. Code ANN. § 30-14-104; OHIO REV. CodE ANN. § 1345.02(C) (West 2004 \& Supp. 2014); 6 R.I. GEN. LAWS ANN. § 6-13.1-3 (West 2006).

21. See, e.g., ARIZ. Rev. Stat. AnN. § 44-1522 (2013 \& Supp. 2015); Conn. Gen. Stat. ANN. § 42-110(b) (West 2012); ME. ReV. STAT. AnN. tit. 5, § 207(1) (West 2013); MASS. GeN. LAWS ANN. ch. 93A, § 2(b) (West 2006); N.H. REV. STAT. ANN. § 358-A:13 (2009); N.M. STAT. ANN. § 57-12-4 (West 2003); S.C. CoDE ANN. § 39-5-20(b) (1985); VT. STAT. ANN. tit. 9, § 2453(b) (West 2007 \& Supp. 2013); WASH. ReV. CODE ANN. § 19.86 .920 (West 2013); W. VA. CodE ANN. $\S 46 \mathrm{~A}-6-101$ (West 2002).

22. See, e.g., GA. Code AnN. § 10-1-391 (West 2003); TEnN. Code AnN. § 47-18-115 (West 2002 \& Supp. 2014); UTAH CODE ANN. § 13-11-2(4) (West 2010).

23. See 51 CONG. REC. 13099, 13101 (1914) (statement of Sen. Newlands).

24. See 15 U.S.C. §§ 45(a), 52(a)(1), 54(a) (2012); Holloway v. Bristol-Myers Corp., 485 F.2d 986, 987 (D.C. Cir. 1973).

25. See 15 U.S.C. § 53(b) (2012) (requiring the Commission to find that bringing an action in federal court to enjoin a violation of the FTC Act is in the public interest).

26. See S. REP. NO. 74-1705, at 1 (1936).

27. See 15 U.S.C. §§ 45(b), 53(b), 57(b) (2012).

28. See id. § 45(m)(1)(B) (2012).

29. See id. § 45(l)-(m) (2012). 
UDAP laws also empower state AGs to seek restitution and injunctions. ${ }^{30}$ Unlike federal law, however, most UDAP laws allow the AG to immediately seek civil penalties, ${ }^{31}$ which can range from a maximum of $\$ 1,000$ to $\$ 50,000$ per violation. ${ }^{32}$ Even for the states with a relatively low maximum penalty, these civil penalties can be substantial considering that the "per violation" penalty can be based on every prescription filled, letter sent, product sold, or advertisement published or aired. Rhode Island is the only state that follows the FTC model and requires a violation of the terms of an injunction before imposing civil penalties. ${ }^{33}$

UDAP laws also provide for wider enforcement than the FTC Act. Unlike the FTC Act, some UDAP laws allow for local enforcement by county district attorneys and city attorneys. ${ }^{34}$ In addition, all UDAP laws provide for a private right of action, ${ }^{35}$ and some allow for consumer class

30. See, e.g., ARK. Code ANN. § 4-88-113 (West 2004); DeL. CodE ANN. tit. 6, §§ 2522, 2523 (West 2011 \& Supp. 2016); GA. CODE ANN. § 10-1-397 (West 2003 \& Supp. 2013); IDAHO CoDE ANN. § 48-606 (West 2006); 815 Ill. Comp. STAT. ANN. 505/7 (West 2008); IND. CoDE ANN. § 245-0.5-4 (West 2006 \& Supp. 2013); IOWA Code ANN. § 714.16 (West 2003); ME. ReV. Stat. ANN. tit. 5, § 209 (West 2013); MASs. Gen. LAWS ANN. ch. 93A, § 4 (West 2006); Mo. ANN. STAT. § 407.100 (West 2011); N.H. Rev. STAT. ANN. § 358-A:4 (2009); OHIO REV. Code ANN. § 1345.07 (West 2004 \& Supp. 2014); OKLA. STAT. ANN. tit. 15, § 756.1 (West 2013); 6 R.I. GEN. LAWS ANN. § 6-13.1-5 (West 2006); TENN. Code ANN. § 47-18-108 (West 2002); Tex. Bus. \& Com. Code AnN. § 17.47 (West 2011); VT. STAT. ANN. tit. 9, § 2458 (West 2007 \& Supp. 2013).

31. See, e.g., ARK. Code AnN. § 4-88-113 (2003); CAL. Bus. \& PROF. Code § 17206 (West 2008 \& Supp. 2014); Del. Code AnN. tit. 6, § 2522(b) (West 2011 \& Supp. 2016); Fla. STAT. ANN. § 501.2075 (West 2010); IND. CodE ANN. § 24-5-0.5-4(g) (West 2006 \& Supp. 2013); KaN. StAT. ANN. § 50-636 (2005); Miss. Code ANN. § 75-24-19(1)(b) (West 1999); N.H. Rev. STAT. ANN. § 358-A:4(III)(b) (2009); N.J. STAT. ANN. § 56:8-13 (West 2012); OKLA. STAT. AnN. tit. 15, § 761.1(C) (West 2013); 73 Pa. STAT. AND Cons. STAT. ANN. § 2018 (West 2008); VT. STAT. ANN. tit. 9, § 2458(b)(1) (West 2007 \& Supp. 2013); Wis. StAT. ANN. § 100.26 (West 2010); Wyo. STAT. ANN. § 40-12-113 (West 2007).

32. See, e.g., D.C. CODE ANN. § 28-3905(i) (West 2015) (\$1,000); 815 ILl. Comp. STAt. AnN. 505/7(b) (West 2008) (\$50,000).

33. See 6 R.I. GEN. LAWS ANN. § 6-13.1-8 (West 2006). A handful of other states require the state AG to contact a business before filing a UDAP enforcement action, but permit the AG to seek civil penalties even if the business offers to immediately address the concern. See, e.g., ME. REv. StAT. ANN. tit. 5, § 209 (West 2013) (requiring AG to provide a person with at least ten days' notice of the intended action, and give the person an opportunity to confer with the AG); N.Y. GEN. BUS. LAW § 349(c) (McKinney 2012) (requiring AG to give business notice and an opportunity to show in writing within five business days why proceedings should not be instituted, unless AG finds notice is not in the public interest); TENN. CODE ANN. § 47-18-108(a)(2) (West 2002) (requiring ten days' notice).

34. See, e.g., Ala. Code § 8-19-4(a)(1)-(3) (2002); CAL. Bus. \& PROF. Code §§ 17203-06 (West 2008 \& Supp. 2014); 815 IlL. Comp. STAT. ANN. 505/7(a)-(b) (West 2008); Miss. Code ANN. § 75-24-21 (West 1999); Mo. ANN. STAT. § 407.020(4) (West 2011 \& Supp. 2016); S.C. CodE ANN. § 39-5-130 (1985); TEX. Bus. \& CoM. CodE ANN. § 17.48 (West 2011); VA. CodE ANN. §§ 59.1-201(A), 59.1-201.1 (West 2011).

35. See Henry N. Butler \& Joshua D. Wright, Are State Consumer Protection Acts Really Little-FTC Acts?, 63 FLA. L. REV. 163, 173 (2011). 
or representative actions. ${ }^{36}$ When Congress debated the FTC Act, a private right of action was considered and rejected due in part to concern with the potential for abusive litigation. ${ }^{37}$ The legislative history of the FTC Act shows that the primacy of the Commission in setting consumer protection policy was an essential consideration at its inception. ${ }^{38}$

Enforcement of the FTC Act is placed solely with the government regulators, not private attorneys. An executive order prohibits federal agencies from hiring outside lawyers on a contingency-fee basis. ${ }^{39}$ Most state AGs do not have this limitation, and AGs, as well as local county district attorneys and city attorneys, have retained outside lawyers to represent the government on a contingency-fee basis to pursue their UDAP enforcement actions. The ability to hire contingency-fee attorneys diminishes some of the safeguards that were built into the FTC Act to help alleviate congressional concerns over the broad types of claims that could be pursued and the potential for abuse. By using contingency-fee arrangements, the AG is not constrained by the budget or staff of his or her office, nor does the AG need to prioritize claims that most benefit the public welfare. In addition, a private attorney's financial interest in a monetary award creates a strong incentive to seek the maximum civil penalty rather than an immediate injunction or other corrective action, which might be more appropriate in certain cases. The disincentives to first seek equitable relief turn the UDAP action into a penal rather than a cooperative and preventive action.

Another difference is the level of proof required to show a violation. Most UDAP laws do not require an AG to show that the consumer relied on the defendant's allegedly deceptive act. ${ }^{40}$ In some states, all an AG

36. See, e.g., D.C. CodE ANN. § 28-3905(k)(1)(B) (West 2015); IdAHO CODE ANN. § 48608(1) (West 2006 \& Supp. 2013); IND. CODE ANN. § 24-5-0.5-4(b) (West 2006 \& Supp. 2013); Kan. StAT. ANN. § 50-634(c), (d) (2005); MASs. GEN. LAWS ANN. ch. 93A, § 9(2) (West 2006); Mo. AnN. Stat. § 407.025(2) (West 2011); OHio Rev. Code AnN. § 1345.09(B) (West 2004 \& Supp. 2014); OR. REV. STAT. ANN. § 646.638(8) (West 2011 \& Supp. 2014); 6 R.I. GEN. LAWS ANN. § 6-13.1-5.2(b) (West 2006).

37. See 51 CONG. REC. 13099, 13106 (1914) (statement of Sen. Stone).

38. See Schwartz \& Silverman, supra note 3, at 7-15 (discussing the legislative history of the FTC Act).

39. See Exec. Order No. 13,433, Protecting American Taxpayers from Payment of Contingency Fees, 72 Fed. Reg. 28441 (May 16, 2007).

40. See, e.g., ALASKa Stat. AnN. § 45.50 .471 (West 2007 \& Supp. 2014); ARIZ. ReV. Stat. ANN. § 44-1522(A) (2013 \& Supp. 2015); DEL. CODE ANN. tit. 6, § 2513(a) (West 2011); 815 ILL. COMP. STAT. ANN. 505/2 (West 2008); IOWA CODE ANN. § 714.16(2)(a) (West 2003); KAN. STAT. ANN. § 50-626(b) (2005 \& Supp. 2015); Ky. REv. STAT. ANN. § 367.170 (West 2006); MD. CoDE ANN., CoM. LAW § 13-301 (West 2013); MinN. STAT. ANN. § 325F.69(1) (2011); Mo. ANN. STAT. § 407.020(3) (West 2011 \& Supp. 2016); NEV. REV. STAT. ANN. § 598.0915 (West 2014); N.D. CENT. CODE ANN. § 51-15-02 (West 2008); S.C. CODE ANN. § 39-5-110(a), (c) (1985); W. VA. CODE ANN. 
needs to show to establish a UDAP violation is that the representation had the tendency to deceive or was capable of misleading someone, and it is typically not necessary to prove that a consumer was actually injured by the alleged misrepresentation. ${ }^{41}$ On the other hand, the FTC has moved away from a tendency or capacity to deceive the general public and adopted more of a "reasonable" consumer standard. ${ }^{42}$ Under this standard, a practice or omission is deceptive if (1) it is likely to mislead consumers; (2) the consumer's interpretation of the representation is "reasonable" under the circumstances; and (3) the representation is "material" in that it is likely to affect either a consumer's choice of whether to purchase a product or the consumer's health or safety in its use. $^{43}$ In order to qualify as "unfair" the FTC requires that the act "causes or is likely to cause substantial injury to consumers which is not reasonably avoidable by consumers themselves and not outweighed by countervailing benefits to consumers or to competition." 44

The daily enforcement of UDAP laws by AGs is generally uncontroversial and can often benefit the public. AGs receive complaints, conduct investigations, and mediate disputes. AGs take action to immediately stop illegal conduct and, where appropriate, seek refunds or other relief for affected consumers. The differences between UDAP laws and the FTC Act, however, can create opportunities for abuse. The government's ability to immediately seek large civil penalties, investigate and litigate through contingency-fee attorneys, and rely on a low standard of proof creates a strong incentive for states to

§ 46A-6-102(7)(M) (West Supp. 2013); see also VT. Stat. ANN. tit. 9, § 2461(b) (West 2007) (requiring either reliance or that consumer "sustain[] damages or injury as a result of any false or fraudulent ... [prohibited] practice[s]").

41. See, e.g., D.C. CODE ANN. § 28-3904 (West 2015) (stating that a person violates the law "whether or not any consumer is in fact misled, deceived or damaged thereby"); MD. CODE ANN., CoM. LAW §§ 13-301(1), 13-302 (West 2013) (providing that the capacity or tendency to deceive establishes a violation "whether or not any consumer in fact has been misled, deceived, or damaged as a result of that practice"); People ex rel. Lockyer v. Fremont Life Ins. Co., 128 Cal. Rptr. 2d 463, 470-471 (Cal. Ct. App. 2002) (finding the test is "whether the public is likely to be deceived ... even if no one was actually deceived, relied upon the fraudulent practice, or sustained any damage.") (citing State Farm Fire \& Cas. Co. v. Superior Court, 53 Cal. Rptr. 2d 229, 235 (Cal. Ct. App. 1996)); State ex rel. McLeod v. Brown, 294 S.E.2d 781, 783 (S.C. 1982) (finding a tendency to deceive and mislead without proof of actual deception is sufficient to establish liability).

42. See Letter from James C. Miller III, FTC Chairman, to Rep. John D. Dingell, Chairman of House Comm'n on Energy \& Commerce, FTC Policy Statement on Deception 1 (Oct. 14, 1983), https://www.ftc.gov/system/files/documents/public_statements/410531/831014deceptionstmt.pdf.

43. See id. at $1-2$.

44. See Federal Trade Commission Act Amendments of 1994, Pub. L. No. 103-312, § 9, 108 Stat. 1691, 1695 (1994) (codified at 15 U.S.C. § 45(n) (2012)) (explaining when an act or practice can be declared unlawful on the ground that it is unfair). 
bring UDAP actions, especially in cases where the defendant is considered an unpopular industry or viewed as having deep pockets.

\section{FOUR PROBLEMS IN STATE AG ENFORCEMENT OF UDAP LAWS}

\section{A. Contracting Out Enforcement to Private Law Firms}

As noted above, although the federal government does not hire outside counsel on a contingency-fee basis to pursue consumer protection or other enforcement actions, ${ }^{45}$ this practice is common with respect to certain types of UDAP actions brought by AGs.

A common thread through many of the UDAP enforcement actions that have raised controversy is that they did not originate with a government-identified need to protect consumers. Rather, private attorneys develop the theories of liability, approach state AGs, and then litigate the state's enforcement action in exchange for a contingency fee. For example, when Pennsylvania AG Linda Kelly hired outside counsel in 2012 to investigate the state's nursing home industry, the Philadelphia Inquirer reported that "it was Cohen Milstein that dreamed up the initiative and sold it to the Attorney General's Office to obtain a no-bid contract." 46

Some AGs have retained law firms to represent their states through no-bid contracts. In Louisiana, outside lawyers hired by former AG Buddy Caldwell collected more than $\$ 54$ million during his tenure. ${ }^{47}$ The law firms he hired included those of his campaign manager and treasurer, whose firms and relatives gave thousands to the AG's

45. Exec. Order No. 13,433, supra note 39.

46. Craig R. McCoy \& Angela Couloumbis, As Penna. Targets Nursing Homes, Law Firm Could Benefit, PHILA. INQUIRER (June 1, 2015), http://articles.philly.com/2015-0601/news/62882740_1_kathleen-kane-nursing-homes-law-firm; see also Andrew Staub, Pennsylvania AG's Use of Outside Law Firms Draws Scrutiny, PA. WATCHDog (Sept. 2, 2015), http://watchdog.org/236326/contingency-fee-law-firms-kane/. Cohen Milstein Sellers \& Toll PLLC, for example, has an entire section devoted to generating state AG actions. See Practice Areas: Public Client, COHEN MiLsteIn, http://www.cohenmilstein.com/practice-area/public-client (last visited Oct. 6, 2016). The firm, which is known for bringing class action lawsuits, donated over $\$ 70,000$ to state AG campaigns between 2010 and 2015. See Jessica M. Karmasek, Cohen Milstein Law Firm Strengthening Relationships with State AGs, Earning Millions, LEGAL NEWSLINE (Apr. 21, 2015), http://legalnewsline.com/stories/510550711-cohen-milstein-law-firm-strengtheningrelationships-with-state-ags-earning-millions.

47. See Eric Lipton, Lawyers Create Big Paydays by Coaxing Attorneys General to Sue, N.Y. TiMES (Dec. 8, 2014), http://www.nytimes.com/2014/12/19/us/politics/lawyers-create-big-paydaysby-coaxing-attorneys-general-to-sue-.html?_r=1. 
campaigns. ${ }^{48}$ Even after the Louisiana legislature passed a law clarifying that state law prohibits state officials from hiring outside lawyers on a contingency-fee basis without legislative authorization, Caldwell contracted out seven new UDAP lawsuits on the basis that they fell under retention agreements approved before the law took effect. ${ }^{49}$ Jeff Landry, Caldwell's successor, cancelled many of these contracts entered by Caldwell, citing a "pattern of abuse." 50

Legal scholarship, ${ }^{51}$ think tank papers, ${ }^{52}$ reports, ${ }^{53}$ congressional testimony, ${ }^{54}$ and the mainstream media have widely criticized state hiring of outside counsel on a contingency-fee basis. ${ }^{55}$ Critics note that such arrangements raise conflicts of interest and ethical and constitutional

48. See, e.g., David Hammer, New Questions Emerge About Outgoing AG Caldwell's Contracts, 4 WWL-TV (Nov. 24, 2015), http:/www.wwltv.com/news/local/investigations/davidhammer/new-questions-emerge-about-outgoing-ag-caldwellscontracts_20160219040938198/47981732.

49. See id.

50. David Hammer, Attorney General Announces Policy Changes After Eyewitness Investigations, 4 WWL-TV (Feb. 18, 2016), http://www.wwltv.com/news/local/investigations/davidhammer/attorney-general-announces-policy-changes-after-eyewitness-investigations/59183853.

51. See, e.g., Martin H. Redish, Private Contingent Fee Lawyers and Public Power: Constitutional and Political Implications, 18 SuP. CT. ECON. REV. 77 (2010); see also Richard O. Faulk \& John S. Gray, Alchemy in the Courtroom? The Transmutation of Public Nuisance Litigation, 2007 MiCH. ST. L. REV. 941, 968; Leah Godesky, Comment, State Attorneys General and Contingency Fee Arrangements: An Affront to the Neutrality Doctrine?, 42 CoLUM. J.L. \& Soc. ProBs. 587 (2009); Katherine McDonald, Comment, "Pay to Sue" - Contingency-Fee Arrangements When Representing the State: A Review of Section 25-16-702 of the Arkansas Code, 66 ARK. L. REV. 775 (2013).

52. See, e.g., James R. Copland, Trial Lawyers, Inc.: Attorneys General - A Report on the Alliance Between State AGs and the Plaintiffs' Bar, Manhattan Inst., CENTER FOR LEGAL POLICY (2011), https://www.manhattan-institute.org/html/trial-lawyers-inc-attorneys-general-report-alliancebetween-state-ags-and-plaintiffs-bar-2011.

53. See Inst. for Legal Reform, U.S. Chamber, Lawsuit Ecosystem II: New Trends, Targets and Players 95-109 (2014), http://www.instituteforlegalreform.com/uploads/sites/

1/evolving.pdf; Inst. for Legal Reform, U.S. Chamber, Unprincipled Prosecution: Abuse of Power and Profiteering in the New 'Litigation Swarm' (2014), http://www.instituteforlegalreform.com/uploads/sites/1/unprincipled-prosecution.pdf; Inst. for Legal Reform, U.S. Chamber, Privatizing Public Enforcement: The Legal, Ethical and Due-Process Implications of Contingency-Fee Arrangements in the Public Sector (2013), http://www.instituteforlegalreform.com/uploads/sites/1/PublicInterestPrivateProfit_FINAL. pdf.

54. See Contingent Fees and Conflicts of Interest in State AG Enforcement of Federal Law: Hearing Before the Subcomm. on the Constitution of the H. Comm. on the Judiciary, $112^{\text {th }}$ Cong. (2012) (statement of the Hon. William McCollum, former Fla. AG, on behalf of the U.S. Chamber of Commerce and the U.S. Chamber Inst. For Legal Reform), https://www.gpo.gov/fdsys/pkg/CHRG112hhrg72692/html/CHRG-112hhrg72692.htm; id. (statement of James R. Copeland, Dir. and Senior Fellow, Ctr. for Legal Policy, Manhattan Inst. for Policy Research).

55. See, e.g., Eric Lipton, supra note 47; Editorial, The Pay-to-Sue-Business, WALL ST. J. (Apr. 16, 2009), http://www.wsj.com/articles/SB123984994639523745. 
concerns, ${ }^{56}$ and contribute to a "pay-to-play" culture as the hired law firms often contribute heavily to AG campaigns. ${ }^{57}$ For instance, over the past decade, Mississippi AG Jim Hood received \$395,000 in campaign contributions from outside attorneys, ${ }^{58}$ and in turn, outside attorneys hired by AG Hood have made nearly $\$ 90$ million in attorney fees and expenses in just the past five years. ${ }^{59}$ Some question whether government enforcement actions brought through private lawyers hired on a contingency-fee basis leads to actions that protect consumers or primarily benefit private lawyers and the AGs who hire them.

In some cases, AGs have delegated the state's broad subpoena power, allowing private lawyers to investigate whether the state should bring an enforcement action-the only way the law firm will be compensated for the work of its attorneys. For instance, the Pennsylvania Attorney General's Office has about 180 lawyers on staff, but, as attorney general, Kathleen Kane retained four private law firms that made significant contributions to her campaigns between 2011 and 2013 to conduct such investigations. ${ }^{60}$ Between March and August 2014, the state served subpoenas on for-profit nursing homes operating in Pennsylvania. ${ }^{61}$ These subpoenas were issued by a Cohen Milstein paralegal acting as "representative of the attorney general authorized to serve a subpoena" in conjunction with a deputy state attorney general,

56. The U.S. Supreme Court has warned that a "scheme injecting a personal interest, financial or otherwise, into the enforcement process may bring irrelevant or impermissible factors into the prosecutorial decision and in some contexts raise serious constitutional questions.” Marshall v. Jerrico, Inc., 446 U.S. 238, 249-50 (1980) (rejecting constitutional challenge but nonetheless recognizing requirement of neutrality and impartiality in enforcement proceeding); see also Tumey v. Ohio, 273 U.S. 510, 532 (1927). The Court has also recognized that private attorneys appointed to represent the government "certainly should be as disinterested as a public prosecutor who undertakes such a prosecution.” Young v. United States ex rel. Vuitton et Fils S.A., 481 U.S. 787, 804 (1987) (precluding lawyers prosecuting a criminal contempt action against individuals who violated an injunction against trademark infringement from having a financial stake in the case).

57. See Lipton, supra note 47.

58. See id. (reporting that the campaign contributions received by AG Hood over the past decade were more than any other AG during that time).

59. See Office of the Attorney General State of Miss., Attorney General Contingent Fund Attorneys Fees and Expenses (June 16, 2016), http://www.ago.state.ms.us/ wp-content/uploads/2016/07/Contingent-Fund-Attorney-Payments.pdf.

60. Brad Bumsted, State's No-Bid Contracts with Private Law Firms Prompt Scrutiny, TRIB. LIVE (Jan. 24, 2015, 10:00 PM), http://triblive.com/politics/politicalheadlines/7507979-74/generalkane-firms (reporting nearly $\$ 200,000$ in contributions to Kane’s campaigns from the law firms hired to conduct investigations and noting that the lawyers and staff of nine law firms holding contracts with AG Kane’s office collectively donated \$362,199 to her campaign).

61. Id. An attorney representing the nursing home chains observed that the lawsuit appeared to target nursing homes "based on their apparent wealth," as the state's action did not include notfor-profit establishments to which the claims could equally apply. McCoy \& Couloumbis, supra note 46. 
and served by the law firm. ${ }^{62}$ Kane then brought an action against the facilities, claiming the nursing homes violated Pennsylvania's Unfair Trade Practices and Consumer Protection Law because the facilities' staffing levels were inadequate to support statements of quality service included in marketing. ${ }^{63}$

Private attorneys representing the state may exercise significant control over the theories alleged and the day-to-day litigation of the case. Most courts have not categorically barred AGs from hiring attorneys on a contingency-fee basis to litigate civil cases, ${ }^{64}$ but several courts have required government lawyers to exert some degree of control over the litigation. $^{65}$ In practice, however, this test has been fairly easy to satisfy. ${ }^{66}$ Some courts have found that a statement in the retention agreement providing that the government retains ultimate control over the litigation and a minimal showing of government involvement in the litigation and any settlement may be sufficient. ${ }^{67}$

For example, in 2009, Kentucky AG Jack Conway filed a lawsuit against Merck under the Kentucky Consumer Protection Act for claims related to the company's marketing of Vioxx. About one year after filing the claim, AG Conway retained an outside law firm to litigate the case on a contingency-fee basis. Merck sought relief in federal court, arguing that the outside counsel, Garmer \& Prather, controlled the litigation. The pharmaceutical maker presented specific examples showing how the government attorney charged with overseeing the litigation lacked real involvement. ${ }^{68}$ Merck pointed out that the contract required that the

62. McCoy \& Couloumbis, supra note 46.

63. Complaint and Petition for Injunctive Relief at 1, 5, Commonwealth v. Golden Gate Nat'l Senior Care LLC, No. 336 MD 2015 (Pa. Commw. Ct. July 1, 2015).

64. But see Meredith v. Ieyoub, 700 So. 2d 478, 484 (La. 1997) (ruling that Louisiana's Attorney General lacked authority to enter into contingency-fee contracts with private lawyers to represent the state and that, absent legislative authorization, such contracts violate state law).

65. See Cty. of Santa Clara v. Superior Court, 235 P.3d 21, 36 (Cal. 2010); State v. Lead Indus. Ass'n, 951 A.2d 428, 475 (R.I. 2008).

66. See Merck Sharp \& Dohme Corp. v. Conway, 947 F. Supp. 2d 733, 733 (E.D. Ky. 2013); Cephalon Inc. v. Wilson, No. 2012-cp-40-07317, at 8-9 (S.C. Ct. Com. Pl., 5th Jud. Cir., June 2, 2014) (Order Granting Defendant's Motion for Summary Judgment); State ex rel. Discover Fin. Servs., Inc. v. Nibert, 744 S.E.2d 625, 639-40 (W. Va. 2013); Maria Chutchian, SC AG Can't Skirt AstraZeneca Improper Penalty Claims, LAw360 (Dec. 21, 2011), http://www.law360.com/articles/ 295720/scagcantskirtastrazenecaimproperpenaltyclaims?.

67. Pennsylvania's high court has insulated agreements between state officials and private lawyers from judicial scrutiny by finding that those named as defendants lack standing to challenge the state's retention practices. See Commonwealth v. Janssen Pharmaceutica, Inc., 8 A.3d 267, 27677 (Pa. 2010).

68. Merck, 947 F. Supp. 2d at 733; see also Alison Frankel, Judge: Kentucky AG Can Use Contingency-Fee Lawyers in Case vs Merck, ReUTERS (May 28, 2013), 
outside counsel assume a "lead role in investigating and ... preparing [the] litigation." 69 The AG's staff failed to make any "substantive revisions" or contributions to court filings. ${ }^{70}$ Outside counsel submitted the briefs filed in the multi-district litigation, signed letters to the court, and rejected a settlement offer. ${ }^{71}$ The government attorney responsible for supervising the litigation only participated in some status conferences, never spoke on the record, could only identify the role of seven of the state's sixty-five witnesses, and did not know whether the state had retained expert witnesses. ${ }^{72}$

The federal district court considering the case, however, did not find the government's lack of knowledge of the details of its own enforcement action troubling. Rather, it viewed the government's attorney as "performing poorly on a few 'pop quizzes.",73 But the court did find one close call: the list of forty-five claimed violations of the Kentucky Consumer Protection Act was cut-and-pasted from one produced by the same outside counsel in a lawsuit brought on behalf of the State of Alaska. ${ }^{74}$ The court viewed the government's lack of involvement in shaping the claims as a "disappointingly casual approach." 75 Nevertheless, the court concluded that the AG retained and exercised decision making authority in the underlying litigation and Merck's due process rights were not violated. ${ }^{76}$ Merck appealed, but the underlying litigation settled before a Sixth Circuit decision.

Delegating government law enforcement authority can also complicate settlement because outside counsel with a contingency-fee arrangement have an incentive to seek the highest recovery, rather than agree to injunctive or other relief. Some retention agreements between states and private lawyers have limited the ability of a state to settle for nonmonetary relief. For example, when Nevada AG Catherine Cortez Masto hired attorneys at Cohen Milstein to sue Lender Processing Services (LPS) over its alleged misconduct in providing support services

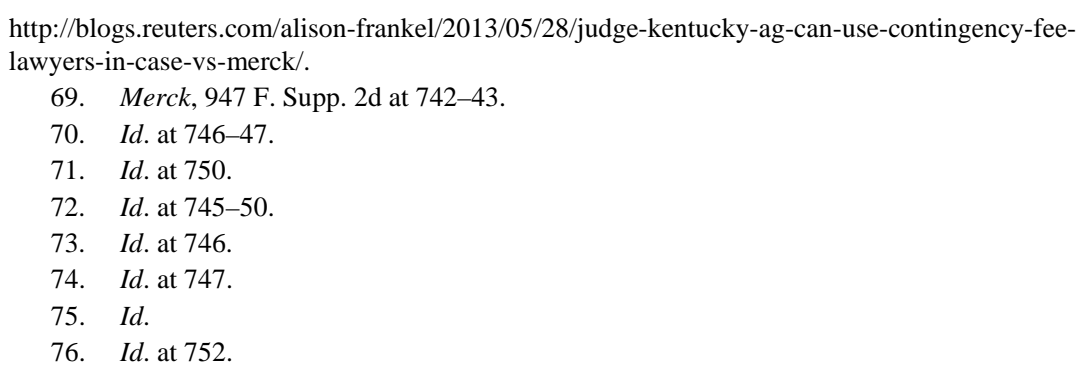


for mortgage lenders, ${ }^{77}$ the retention agreement gave the private firm "virtual veto power" over any settlement offer. ${ }^{78}$ The AG's office agreed not to settle claims against the mortgage lender for injunctive relief unless the defendant provided costs and hourly fees for the law firm's services. ${ }^{79}$ Forty-six states and the District of Columbia settled UDAP claims with the company in January $2013,{ }^{80}$ following earlier settlements with three individual states. ${ }^{81}$ Nevada, the only state to hire lawyers on a contingency-fee basis to pursue LPS, held out. ${ }^{82}$ As a lawyer for the company observed, the Nevada case continued "because they have a class-action law firm running this. The attorney general is not running this." ${ }^{83}$ Only after a state court judge sanctioned the state for failing to produce evidence of the number of consumer protection violations the state had alleged, ${ }^{84}$ did the litigation settle. ${ }^{85}$

Pennsylvania's retention agreement with Cohen Milstein to investigate nursing home practices had a similar restriction on settlement. Initially, a provision in the contract barred the state from settling the lawsuit other than for a financial payment. The state could not, for example, accept a promise from the facilities to increase staffing or

77. Complaint, Nevada v. Lender Processing Servs. Inc., No. A-11-653289-B (Nev. Dist. Ct., 8th Judicial Dist., Dec. 15, 2011).

78. Amanda Bronstad, Cohen Milstein Role Under Fire in Robo-Signing Case, AM. LAWYER (June 3, 2013), http://www.litigationdaily.com/id=1202602750436.

79. Nevada's actions reportedly threatened to unravel LPS's settlement with other states because the agreement allowed states to renegotiate if any state gets a different deal. See Editorial, What Doesn't Stay in Vegas, WALL ST. J. (June 11, 2013), http://www.wsj.com/articles/SB1000 1424127887323469804578523700441000298.

80. David McLaughlin, LPS Reaches $\$ 120$ Million Deal in 'Robosigning' Probe, BLOOMBERG BusINESS (Jan. 31, 2013), http://www.bloomberg.com/news/articles/2013-01-31/lps-reaches-120million-deal-with-states-in-foreclosure-probe.

81. Chris Sieroty, Nevada Is Last State Standing as Mortgage Processor Reaches Settlement, LAS VEGAS REV.-J. (Jan. 31, 2013), http://www.reviewjournal.com/business/housing/nevada-laststate-standing-mortgage-processor-reaches-settlement.

82. See Editorial, What Doesn't Stay in Vegas, WALL St. J. (June 11, 2013), http://www.wsj.com /articles/ SB10001424127887323469804578523700441000298.

83. Tim O’Reiley, Sanctions Could Cost Nevada Attorney General \$1 Million or More, LAS VEGAS REV.-J. (Jan. 30, 2014), http://www.reviewjournal.com/business/sanctions-could-costnevada-attorney-general-1-million-or-more (quoting Mitchell Berger).

84. See Ken Ritter, Nevada AG Sanctioned in Lender Fraud Civil Lawsuit, LAS Vegas SuN (Jan. 31, 2014), http://lasvegassun.com/news/2014/jan/31/nevada-ag-sanctioned-lender-fraud-civillawsuit/; Andrew Scurria, Nev. AG Sanctioned in Lender Processing Fraud Suit, LAW360 (Jan. 31, 2014), http://www.law360.com/articles/505918/nev-ag-sanctioned-in-lender-processing-fraudsuit?article_related_content $=1$.

85. See Ken Ritter, Nevada AG Takes Deal in Lender Fraud Civil Lawsuit, ElKo DAILY FreE PRESS (Feb. 16, 2014), http://elkodaily.com/news/nevada-ag-takes-deal-in-lender-fraud-civillawsuit/article_0e582bec-973c-11e3-aa7c-001a4bcf887a.html. 
otherwise improve conditions. ${ }^{86}$ The agreement was later amended to allow a settlement that provides injunctive relief but no financial recovery, while requiring the AG's office to "use its best efforts to negotiate for the payment of reasonable attorneys' fees as a settlement term." 87

Even where the retention agreement does not restrict nonmonetary settlements, such arrangements may permit a law firm to make unreasonable demands that do not serve consumer interests. For instance, in multi-state litigation claiming that Eli Lilly violated UDAP and other laws by marketing Zyprexa for purposes other than treating schizophrenia or bipolar disorder, Bailey Perrin Bailey (BPB) was the main settlement holdout. BPB handled the Zyprexa litigation for three states-Arkansas, Mississippi, and Pennsylvania — and were among a group of law firms representing South Carolina. ${ }^{88}$ Thirty-three states that sued Lilly entered a $\$ 62$ million settlement in October 2008. ${ }^{89}$ Several additional states (also represented by outside counsel) followed, entering individual settlements. With the exception of Pennsylvania, the states represented by BPB were among the few hold outs. ${ }^{90}$ These "slash-andburn" tactics backfired after a federal judge dismissed most of Mississippi’s claims. ${ }^{91}$ Faced with the possibility of collecting nothing, Mississippi AG Jim Hood entered an \$18.5 million settlement with Eli Lilly in February 2010 - an amount that was a fraction of the civil penalties BPB had sought. ${ }^{92}$ Arkansas settled for the same amount at that time. ${ }^{93}$ In the settlements resolving the Mississippi and Arkansas

86. McCoy \& Couloumbis, supra note 46.

87. See Petitioners' Brief in Opposition to Respondents' Preliminary Objections to the Amended Petition for Review, at 5, GGNSC Clarion LP v. Kane, No. 165 MD 2015, at 5 (Pa. Commw. Ct. Sept. 28, 2015) [hereinafter Petitioners’ Brief].

88. The Arkansas and Mississippi arrangements especially raised eyebrows, as Texas-based $\mathrm{BPB}$ and its lawyers had reportedly donated \$70,000 to the Arkansas Democratic Party and \$75,000 to Mississippi attorney general Jim Hood's reelection campaign. See John O’Brien, Lilly Settles Ark. Suit Brought by Bailey Firm, LEGAL NEWSLINE (Feb. 18, 2010), http://legalnewsline.com/stories/510522422-lilly-settles-ark-suit-brought-by-bailey-firm.

89. See Alex Berenson, 33 States to Get $\$ 62$ Million in Zyprexa Settlement, N.Y. TiMES (Oct. 6, 2008), http://www.nytimes.com/2008/10/07/business/07zyprexa.html.

90. See John O’Brien, Judge Sides with Eli Lilly in Zyprexa Case, LEGAL NEWsLINE (Dec. 1, 2009), http://legalnewsline.com/stories/510521961-judge-sides-with-eli-lilly-in-zyprexa-case; John O’Brien, Zyprexa Settlements Piling Up, Four States Remain, W. VA. REC. (Sept. 21, 2009), http://wvrecord.com/stories/510596826-zyprexa-settlements-piling-up-four-states-remain.

91. See In re Zyprexa Prods. Liab. Litig., 671 F. Supp. 2d 397, 463-64 (E.D.N.Y. 2009).

92. See John O’Brien, Lilly Decides to Settle with AG Hood, LEGAL NEWSLINE (Feb. 4, 2010), http://legalnewsline.com/stories/510522340-lilly-decides-to-settle-with-ag-hood.

93. State v. Eli Lilly \& Co., No. CV-2008-4722 (Ark. Cir. Ct., Pulaski Cty., Feb. 5, 2010) (Consent Judgment and Assurance of Voluntary Compliance). 
litigation, respectively, outside lawyers including BPB received \$3.7 million and \$2.8 million. ${ }^{94}$

\section{B. Regulating Already-Regulated Industries}

Most UDAP laws recognize the value of consistency between the policymaking of regulatory agencies charged with protecting consumers in a particular area and UDAP enforcement actions. Such congruence respects the authority and expertise of government agencies, and provides predictability and fairness for businesses that rely on government decision making. It also recognizes that there are alternative means, often through administrative systems, for addressing consumer complaints regarding regulated conduct.

For these reasons, about two thirds of UDAP laws exempt from their scope conduct that is regulated, permitted, approved, or specifically authorized by state or federal agencies, or complies with government regulations. $^{95}$ The language of these provisions varies from state to state. $^{96}$ A few state laws exempt only conduct that is subject to and complies with FTC rules or orders. ${ }^{97}$ Other state laws are inapplicable to practices regulated by specific state entities, such as a state insurance commission or public utility board. ${ }^{98}$ In some states that lack a statutory regulatory compliance provision, courts have adopted similar principles. ${ }^{99}$

94. Chuck Bartels, Ark. Announces \$18.5 Million Settlement with Eli Lilly, Boston.COM (Feb. 16, 2010), http://archive.boston.com/business/healthcare/articles/2010/02/16/ark_announces_

185m_settlement_with_eli_lilly/.

95. See generally Victor E. Schwartz, Cary Silverman \& Christopher E. Appel, "That's Unfair!" Says Who - The Government or Litigant?: Consumer Protection Claims Involving Regulated Conduct, 47 WASHBURN L.J. 93, 102-09 (2007) (surveying state law).

96. See id.

97. See, e.g., ARIZ. Rev. Stat. AnN. § 44-1523 (2013); Del. Code AnN. tit. 6, § 2513(b)(2) (West 2011); Iowa Code AnN. § 714.16(14) (West 2003); TEx. Bus. \& Comm. Code ANN. § 17.49(b) (West 2011 \& Supp. 2013); 2015 W. Va. Legis. Serv. Ch. 64 (S.B. 315) (2015) (amending W. VA. CODE $\S 46 A-6-101(1))$.

98. DeL. Code ANN. tit. 6, § 2513(b)(3) (West 2011) (inapplicable to practices subject to jurisdiction of Public Service Commission or Insurance Commissioner); LA. STAT. ANN. § 51:1406(1) (2003 \& Supp. 2014) (inapplicable to actions subject to jurisdiction of public service commission, insurance commissioner, financial institutions and insurance regulators of other states, and federal banking regulators); Mo. ANN. STAT. § 407.020 (West 2011 \& Supp. 2016) (generally inapplicable to any company regulated by department of insurance, division of credit unions, or division of finance); MONT. CODE ANN. § 30-14-105(1) (2013) (inapplicable to "actions or transactions permitted under laws administered by the Montana public service commission or the state auditor”); TEX. Bus. \& Comm. CODE ANN. § 17.50(a)(4) (West 2011) (inapplicable to violations of insurance code).

99. See generally Schwartz, Silverman \& Appel, supra note 95, at 102-09. 
Courts are inconsistent, however, in their interpretation and application of these provisions. ${ }^{100}$ For example, some courts have found that their state's UDAP law does not apply to pharmaceutical marketing practices because the FDA already closely regulates them. ${ }^{101}$ Other courts, however, have allowed AGs to use UDAP laws to impose supplemental obligations on a company or industry or, more often, seek to impose civil fines under UDAP laws for what were considered minor (and often corrected) violations of other statutes or regulations.

\section{Use of FDA Warning Letters to Punish Prescription Drug Makers}

AGs have brought a surge of enforcement actions against drug makers challenging their marketing practices. This is an area closely regulated by the FDA. Each year, the FDA's Office of Prescription Drug Promotion (OPDP) (formerly the Division of Drug Marketing, Advertising and Communications) reviews thousands of direct-toconsumer advertisements, "dear doctor" letters, ${ }^{102}$ and other materials disseminated by pharmaceutical companies. ${ }^{103}$ When OPDP staff

100. See id.

101. See, e.g., Bober v. Glaxo Wellcome PLC, 246 F.3d 934, 940-43 (7th Cir. 2001) (finding Illinois Consumer Fraud and Deceptive Business Practices Act does not subject pharmaceutical makers to liability for statements authorized by federal law); Prohias v. Pfizer, Inc., 490 F. Supp. 2d 1228, 1234-35 (S.D. Fla. 2007) (interpreting safe harbors of the Florida and Massachusetts consumer fraud laws); DePriest v. AstraZeneca Pharm., L.P., 351 S.W.3d 168, 178 (Ark. 2009) (finding that statements made in advertising that are supported by the FDA approved labeling fall within the safe harbor provision of the Arkansas Deceptive Trade Practices Act as being actions permitted under the laws administered by the FDA and are not actionable); Prohias v. AstraZeneca Pharm., L.P., 958 So. 2d 1054, 1056 (Fla. Dist. Ct. App. 2007) (noting that claims brought under state law are preempted because they would conflict with federal law and FDA approved labeling); Duronio v. Merck \& Co., No. 267003, 2006 WL 1628516, at *7 (Mich. Ct. App. June 13, 2006) (finding trial court properly dismissed claim under Michigan Consumer Protection Act because the pharmaceutical marketing activities underlying the claim are authorized and regulated under laws administered by the FDA); White v. Wyeth, 705 S.E.2d 828, 838 (W. Va. 2010) (citing N.J. Citizen Action v. Schering-Plough Corp., 842 A.2d 174, 177-78 (N.J. Super. Ct. App. Div. 2003) and De Bouse v. Bayer AG, 922 N.E.2d 309, 318 (Ill. 2009)) (finding, with respect to private rights of action, that the West Virginia Consumer Credit and Protection Act is not intended to cover prescription drug purchases because of the role of the physician in the consumer's purchasing decision and the high degree of federal regulation of prescriptive drug product).

102. "Dear Doctor" letters are also referred to as "Dear Healthcare Provider" letters. State ex rel. McGraw v. Johnson \& Johnson, 704 S.E.2d 677, 682 (W. Va. 2010).

103. OPDP receives 6,000 to 8,000 submissions of pharmaceutical promotional materials each month. See FDA, Keeping Drug Advertising Honest and Balanced, at 2 (2013), http://www.fda.gov/downloads/ForConsumers/ConsumerUpdates/UCM355368.pdf (interview with Thomas Abrams, Director of OPDP). The FDA estimates that it will receive 83,000 submissions in FY 2015. FDA, U.S. DEP’T OF HEALTH \& HuMAN SERVS., FY 2015 JustifiCATIONS OF ESTIMATES FOR APPROPRIATIONS COMMITTEES 48 (2014), http://www.fda.gov/downloads/AboutFDA/Reports ManualsForms/Reports/BudgetReports/UCM388309.pdf. 
identifies a concern with such material, finding that it does not present a balanced assessment of the benefits and risks of the drug, or that it omits pertinent information, OPDP issues a warning letter. ${ }^{104}$

FDA policy recognizes that these warning letters are "informal," "advisory," and "[do] not commit FDA to taking enforcement action."105 The FDA has explained to the U.S. Supreme Court that warning letters do "not mark the consummation of FDA's decisionmaking process," are "not based on a formal and complete administrative record," are merely "tentative," and "do not constitute final agency action." 106 Unlike formal FDA advisory opinions, warning letters are merely the judgment of a particular agency employee and "[do] not necessarily represent the formal position of [the] FDA, and [do] not bind or otherwise obligate or commit the agency to the views expressed." 107 There is no hearing or other process before the agency issues such a letter. Nor is there any finding that the manufacturer's conduct actually misled doctors or their patients. Warning letters are not subject to challenge in court. ${ }^{108}$

Typically, a warning letter requests that the manufacturer stop running an advertisement or issue a corrective letter to healthcare providers. Manufacturers usually voluntarily and promptly comply with

104. OPDP issues enforcement letters asking companies to stop marketing claims that its staff views as unsupported or misleading. These take the form of notice of violation letters (or "untitled letters") for minor issues and warning letters for more serious concerns. OPDP issued nine enforcement letters in 2015 (seven untitled letters and two warning letters), an amount that is less than typical. See FDA, Warning Letters 2015, http://www.fda.gov/Drugs/GuidanceCompliance

RegulatoryInformation/EnforcementActivitiesbyFDA/WarningLettersandNoticeofViolationLettersto PharmaceuticalCompanies/ucm432949.htm\#OPDP (last visited Oct. 3, 2016). OPDP typically issues 30 to 50 enforcement letters each year. See id.

105. FDA, RegUlatory PROCEDUREs MANUAL § 4-1-1 (May 2, 2016), http://www.fda.gov/ ICECI/ComplianceManuals/RegulatoryProceduresManual/ucm176870.htm\#SUB4-1-1 (last visited Oct. 7, 2016).

106. Brief for the Respondents in Opposition at 8-10, Holistic Candlers \& Consumers Ass'n v. FDA, 664 F.3d 940 (D.C. Cir. 2012) (No. 11-1454), 2012 WL 3991471, at *9-10 (citing Bennet v. Spear, 520 U.S. 154, 178 (1997)); see also Cody Labs., Inc. v. Sebelius, No. 10-CV-00147-ABJ, 2010 WL 3119279, at*12 (D. Wyo. July 26, 2010), aff'd in pertinent part, 446 F. Appx. 964 (10th Cir. 2011); Summit Tech., Inc. v. High-Line Med. Instruments Co., 922 F. Supp. 299, 306 (C.D. Cal. 1996) (citing Dietary Supplemental Coal., Inc. v. Sullivan, 978 F.2d 560, 563 (9th Cir. 1992)) ("[R] egardless of any warning letters that the FDA may have sent to Defendants, it is clear that the FDA has not completed this investigation.”).

107. FDA Advisory Opinions, 21 C.F.R. § 10.85(k) (2016).

108. See Holistic Candlers, 664 F.3d at 944 (regarding the warning letters the court stated that "[i]t is plain, therefore, that '[n]o legal consequences flow from the agency's conduct to date, for there has been no order compelling [the appellants] to do anything.'” (quoting Reliable Automatic Sprinkler Co. v. Consumer Product Safety Comm'n, 324 F.3d 726, 732 (D.C. Cir. 2003) (second and third alterations in original)); Biotics Research Corp. v. Heckler, 710 F.2d 1375, 1378 (9th Cir. 1983) (noting that letters do not "constitute a final decision by the FDA.”); Estee Lauder, Inc. v. FDA, 727 F. Supp. 1, 6-7 (D.D.C. 1989) (finding a FDA letter was not the agency's "final position."). 
the FDA's request. According to the FDA, "nearly all of [the issued warning letters] are resolved through discussions between FDA staff and those in the regulated industry."109 After the FDA verifies that the manufacturer has taken corrective action that adequately addresses the concerns expressed in the warning letter, the FDA closes the matter. ${ }^{110}$

While the FDA may view the issue as resolved, some AGs, acting through private counsel, have subsequently brought their own actions that rely on FDA warning letters as evidence of UDAP violations. Cases in West Virginia, Arkansas, and South Carolina targeting the marketing of Risperdal, a drug that treats schizophrenia and symptoms of bipolar disorder, illustrate this trend.

In August 2004, soon after FDA staff issued a warning letter expressing concern that a dear doctor letter Janssen sent to physicians about Risperdal did not adequately address the risks of hyperglycemia and diabetes, then-AG Darrell McGraw, Jr. brought an action under his state's Consumer Credit and Protection Act. ${ }^{111}$ Janssen disputed the FDA's assertions, but voluntarily complied by sending corrective information to doctors. ${ }^{112}$ Following that action, the FDA closed the matter. ${ }^{113}$ McGraw's case was "based entirely on the statements and [alleged] omissions" identified in the FDA's warning letter to Janssen. ${ }^{114}$ The AG sought a civil penalty of \$5,000 for each sales meeting and each dear doctor letter sent by the company to a West Virginia doctor. ${ }^{115}$ The Circuit Court of Brooke County found that the FDA's warning letters conclusively established a violation of the state's UDAP and imposed a $\$ 3,950,000$ civil penalty. ${ }^{116}$

The West Virginia Supreme Court of Appeals reversed, recognizing that when the FDA issues a warning letter it does not provide due process safeguards, such as prior notice, a hearing, or the ability to appeal. ${ }^{117}$ The letter indicates only FDA staff's belief that a violation has

109. Memorandum in Support of Defendant's Motion to Dismiss at 2, Cody Labs., Inc., No. 2:10-CV-00147-ABJ (2010), 2010 WL 3119279.

110. FDA PROCEDURES MANUAL, supra note 105, at § 4-1-8.

111. State ex rel. McGraw v. Johnson \& Johnson, 704 S.E.2d 677, 681-82 (W. Va. 2010).

112. See id.

113. See id. at 683 (emphasis added).

114. See id.

115. See id. at 684 .

116. See Brief for the Appellee at 2, State ex rel. McGraw, 704 S.E.2d 677 (W. Va. 2010), 2010 WL 2824601, at $* 2$. The action also included a similar UDAP claim regarding the company's marketing of Duragesic, a pain reliever. The trial court imposed a $\$ 525,000$ penalty for the company's marketing of Duragesic resulting in a total penalty in the action of $\$ 4,475,000$. See id.; see also State ex rel. McGraw, 704 S.E.2d at 684.

117. See State ex rel. McGraw, 704 S.E.2d at 689-91. 
occurred, but is not conclusive. ${ }^{118}$ "It is fundamental," the court found, "that every defendant is entitled to defend themselves against allegations of misconduct." "119

The Arkansas Supreme Court reached a similar result when AG Dustin McDaniel brought an action against Janssen in 2007, after outside law firms approached his office. ${ }^{120}$ The state alleged violations of the Arkansas Deceptive Trade Practices Act (DTPA) and the Arkansas Medicaid Fraud False Claims Act based on the same dear doctor letter Janssen sent to physicians about Risperdal and the FDA's warning letter. ${ }^{121}$ The state alleged 4,569 DTPA violations, based on the number of dear doctor letters sent to healthcare providers. ${ }^{122}$ The state referred to the warning letter repeatedly during the trial, including at least fifteen times in closing arguments alone. ${ }^{123}$ Upon a jury verdict for the state, the circuit court imposed a $\$ 2,500$ fine per letter for a total of $\$ 11,422,500 .^{124}$ The court awarded an additional $\$ 1.2$ billion under the state's Medicaid fraud statute, imposing a \$5,000 fine for each of 238,874 Risperdal prescriptions filled during the applicable time frame. ${ }^{125}$

The Arkansas Supreme Court reversed the entire judgment. ${ }^{126}$ It found that the FDA warning letter was inadmissible as evidence because the letter was both prohibited hearsay and, even if it fell within an exception to the hearsay rule, it was more prejudicial than probative. ${ }^{127}$ As a government-issued document, the FDA letter carried "inordinate weight" with the jury, yet it was the result of only an informal investigation, the court found. ${ }^{128}$ Given its reversal of the judgment, the Arkansas Supreme Court also reversed the \$180.8 million in attorneys' fees and costs awarded to the state based on its contingency-fee agreement with Bailey Perrin Bailey. ${ }^{129}$

In South Carolina, a similar court judgment partially withstood appellate review. There, then-AG Henry McMaster filed an action

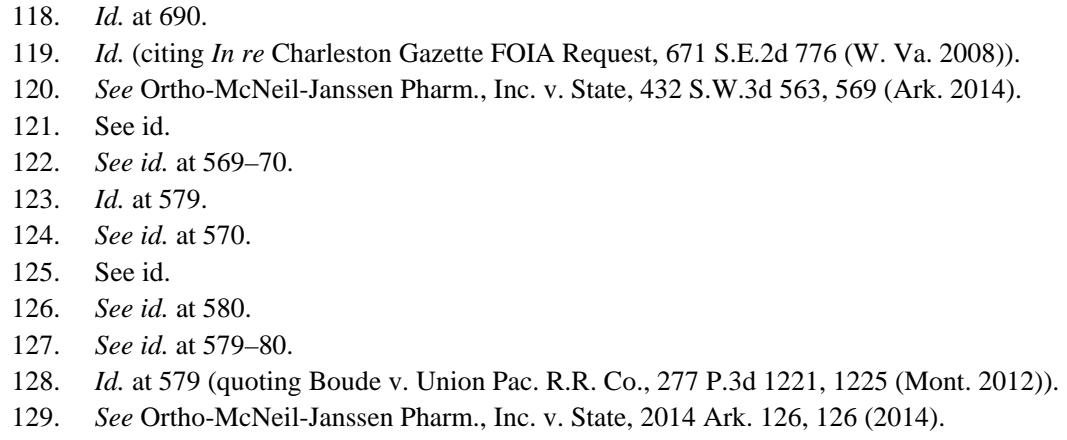


against Janssen under the South Carolina Unfair Trade Practices Act (SCUTPA) premised, in part, on the company's sending the same dear doctor letter to physicians in his state. ${ }^{130}$ Private lawyers hired by McMaster to represent South Carolina ${ }^{131}$ used Janssen's cooperation with the FDA as evidence that its dear doctor letter violated the Act. Plaintiffs' lawyer Donald Coggins, Jr. of Harrison, White, Smith \& Coggins, P.C. stated in his opening argument:

[W] hen [the FDA Warning Letter] came along and issued that warning letter in April and ordered corrective action I think it's instruct[ive] what Janssen did. They could've appealed it, they could have contested it, they could have gone to court about it, they could have asked for some other type of sanction but what did they do? They sent it out just like the FDA told them [to].... [A]nd the [correction] letters clearly show and [sic] acknowledgement that they did wrong doing it. ${ }^{132}$

In closing arguments, Coggins' colleague, John Simmons, made similar assertions:

The FDA concludes that the Dear Doctor Letter was false and misleading in a number of areas.... The FDA said you not only made affirmative misrepresentations in that Dear Doctor Letter, you omitted material information which is to say as being untruthful, which is to say as being imprudent, which is to say to be submitted unfair and deceptive.... [A]fter they received that warning letter, these defendants folded like a cheap suit. The FDA wrote them that [warning] letter in April and said false and misleading.... It called them on what they did. These defendants caved in immediately [and sent a correction letter]. ${ }^{133}$

130. State ex rel. Wilson v. Ortho-McNeil-Janssen Pharm., Inc., 777 S.E.2d 176, 188, 204 (S.C. 2015), cert. denied, 136 S. Ct. 824 (Jan. 11, 2016).

131. See Litigation Retention Agreement for Special Counsel Appointed by the South Carolina Attorney General (Dec. 2010), http://www.scag.gov/wp-content/uploads/2011/09/Antipsychoticslitigation-retention-agreement-Janssen-plus-addenda.pdf; see also John O’Brien, S.C. AG McMaster Taking Contributions from Outside Counsel He Hired, LEgAL NewSLine (Sept. 24, 2009), http://legalnewsline.com/stories/510521545-s-c-ag-mcmaster-taking-contributions-from-outsidecounsel-he-hired. "McMaster, who later ran unsuccessfully for governor, gave back \$32,500 in donations from five lawyers he... hired to work on [these] lawsuits.” See John O’Brien, South Carolina's Risperdal Suit Goes to Trial, LegaL NEwSLine (Mar. 8, 2011), http://legalnewsline.com/ stories/510524330-south-carolina-s-risperdal-suit-goes-to-trial.

132. Unofficial Transcript of Plaintiff's Opening Statement, State ex rel. Wilson v. OrthoMcNeil-Janssen Pharm., Inc., No. 07-CP-42-1438, 2011 WL 2066648, at*12 (S.C. Ct. Com. Pl. Mar. 8, 2011).

133. Unofficial Transcript of Plaintiff's Closing Statement, State ex rel. Wilson, No. 07-CP-421438, 2011 WL 2161889, at *8-9 (S.C. Ct. Com. Pl. Mar. 21, 2011). 
Janssen's counsel responded by pointing out that "[w]arning letters are inform[al], they're advisory," and "[t]hey're not subject to appeal to anyone." 134 The jury determined that Janssen engaged in unfair or deceptive practices in its marketing. ${ }^{135}$ The trial court judge assessed the penalty: $\$ 4,000$ for each of 7,184 dear doctor letters and each of 36,372 follow up sales calls for a total of $\$ 174.2$ million. ${ }^{136}$

The South Carolina Supreme Court found that Janssen failed to preserve the issue of the admissibility of FDA warning letters, but even if it had done so, the court would have found the letters relevant to liability. ${ }^{137}$ The court affirmed the $\$ 4,000$ civil penalty for each dear doctor letter sent, in July 2015. ${ }^{138}$ Recognizing that the follow up sales calls were to the same physicians that had received letters, and in many instances the same physicians received multiple calls, the court remitted the $\$ 4,000$ per call penalty to $\$ 2,000$ per call. ${ }^{139}$ As a result, the court reduced the portion of the civil penalty related to the dear doctor letter to $\$ 101.5$ million. ${ }^{140}$

Pharmaceutical companies have also had to respond to UDAP actions brought by local county district attorneys and city attorneys challenging pharmaceutical marketing. In May 2014, the Orange County, California district attorney and the Santa Clara County district attorney retained outside counsel to bring a UDAP action on behalf of their residents against the major manufacturers of opioid painkillers such as OxyContin and Percocet. ${ }^{141}$ The complaint blames the manufacturers' "aggressive marketing" for problems associated with the "epidemic" of painkiller addictions, including increased use of heroin, and seeks civil penalties, restitution, and injunctive relief. ${ }^{142}$ It alleges that the

134. See id. at *17.

135. State ex rel. Wilson, No. 07-CP-42-1438, 2011 WL 2185861 (S.C. Ct. Com. Pl. June 3, 2011) (Penalty Order). id.

136. See id. The total amount of the judgment including other penalties was \$327 million. See

137. State ex rel. Wilson v. Ortho-McNeil-Janssen Pharm., Inc., 777 S.E.2d 176, 191 (S.C. 2015), cert. denied, 136 S. Ct. 824 (Jan. 11, 2016).

138. See id. at 204-05.

139. See id.

140. See id. at 205.

141. See David McAfee, Calif. Counties Claim Pharma Cos. Lied About Opioid Safety, LAW360 (May 22, 2014), http://www.law360.com/articles/540839/calif-counties-claim-pharma-coslied-about-opioid-safety.

142. See Complaint for Violations of California False Advertising Law, California Unfair Competition Law, and Public Nuisance, Seeking Restitution, Civil Penalties, Abatement, and Injunctive Relief, People v. Purdue Pharma LP, Case No. 2014-00725287, at 10, $96-99$ (Cal. Super. Ct. May 21, 2014), http://assets.law360news.com/0540000/540839/Complaint\%201.pdf. 
manufacturers misrepresented the off-label benefits of using opioids for common non-cancer chronic pain like back pain, arthritis, and headaches. ${ }^{143}$ As with the other pharmaceutical cases discussed above, the complaint references DDMAC warning letters as support for its marketing allegations. ${ }^{144}$ Weeks after the California case was filed, the city of Chicago, through some of the same private lawyers, brought a similar action against the manufacturers. ${ }^{145}$

In the California case, Orange County Superior Court Judge Robert J. Moss granted the manufacturers' motion to stay the case while the FDA studies the scientific and health policy issues regarding long-term opioid use. ${ }^{146}$ The court, exercising its inherent authority to manage its docket, dismissed the case without prejudice in August 2015. ${ }^{147}$ Judge Moss found that " $t]$ his action could lead to inconsistencies with the FDA's findings, inconsistencies among the States, a lack of uniformity, and a potential chilling effect on the prescription of these drugs for those who need them most." ${ }^{148}$ He recognized that the determinations the court would need to make, in order to rule on whether the marketing was improper, falls within the purview of the FDA, and he did not want to involve the court at this point "in an area which is best left to agencies such as the FDA who are designed to address such issues." 149

Nevertheless, the Chicago case is ongoing. Although a federal court declined to disqualify Cohen Milstein Sellers \& Toll PLLC from representing Chicago in December 2014, ${ }^{150}$ the court initially dismissed the case. In a May 2015 ruling, Judge Jorge L. Alonso found that the FDA's authority to regulate opioid marketing did not preclude the lawsuit, but that the city had not provided enough details supporting its consumer fraud allegations, such as a Chicago doctor or consumer who

\footnotetext{
143. See id.

144. See id. at 13-14, 33, 70.

145. Lance Duroni, Chicago Sues Pharma Cos. over Painkiller Marketing, Law360 (June 3, 2014), http://www.law360.com/articles/544124/chicago-sues-pharma-cos-over-painkillermarketing?article_related_content $=1$.

146. Y. Peter Kang, Drug Cos. Win Stay of False Ad Suit over Painkiller Safety, LAw360 (Aug. 28, 2015), http://www.law360.com/articles/696825/drug-cos-win-stay-of-false-ad-suit-overpainkiller-safety; Lisa Girion, Judge Halts Counties' Lawsuit Against 5 Narcotic Drug Manufacturers, L.A. TIMEs (Aug. 27, 2015), http://www.latimes.com/local/california/la-me-pharma20150828-story.html.

147. See People v. Purdue Pharma LP., No. 2014-00725287, 2015 WL 5123273 (Cal. Super. Ct. Aug. 27, 2015) (Order Granting Motion to Stay).

148. See id. at $* 2$.

149. See id.

150. See City of Chicago v. Purdue Pharma L.P., No. 14 C 4361, 2014 WL 7146362, at *9 (N.D. Ill. Dec. 15, 2014) (Memorandum Opinion and Order).
} 
was influenced by a misrepresentation. ${ }^{151}$ The city filed a 300-page amended complaint in November 2015, keeping the suit alive. ${ }^{152}$

\section{Settlements that Impose Obligations Exceeding FDA Requirements}

With the increased number of UDAP enforcement actions, AGs are forming multi-state groups and entering into settlements with pharmaceutical companies that impose new restrictions and obligations over the future marketing of prescription drugs. These multi-state settlements have provided a new layer of state regulation on the marketing of prescription drugs by empowering AGs with the authority to enforce certain FDA regulations and impose additional restrictions above existing FDA regulations.

The practice appears to have originated with the $\$ 58$ million multistate Vioxx settlement in 2008. ${ }^{153}$ In the Vioxx settlement, Merck agreed to both refrain from making promotional claims, including oral statements by its sales representatives, that are false, misleading or deceptive, and to comply with the Federal Food, Drug, and Cosmetic Act ("FD\&C Act") as well as FDA requirements in connection with advertising and promotion. ${ }^{154}$ By agreeing to such terms, Merck effectively granted state AGs the power to enforce violations of FDA regulations-a power AGs do not have under the FD\&C Act.

The settlement also imposed new regulatory obligations on Merck. Merck agreed to "submit all new [Direct to Consumer] television advertising campaigns for any Merck Product to the FDA for pre-review, wait until Merck receives a response from FDA prior to running the advertising campaign, and to modify such advertising consistent with any written comments received from FDA.” ${ }^{155}$ The agreement prevented Merck from running any television ads marketing prescription drugs to consumers until it received a response from the FDA, no matter how

151. See City of Chicago, No. 14 C 4361, 2015 WL 2208423, at *15 (May 8, 2015) (Memorandum Opinion and Order).

152. See Sindhu Sundar, Chicago Improves Opioid Case with Details About Doctors, LAW360 (Nov. 24, 2015), http://www.law360.com/productliability/articles/731091.

153. See Press Release, Or. Dep't of Justice, Or. Office of the Att'y Gen., AG Hardy Myers Files Judgment Against Merck; Oregon Is Lead State in \$58 Million Settlement (May 20, 2008), http://www.doj.state.or.us/releases/pages/2008/rel052008.aspx (last visited Oct. 7, 2016).

154. See Consent Judgment at 5-6, Iowa ex rel. Miller v. Merck \& Co., No. CE 59178 (Iowa Dist. Ct. May 13, 2008) [hereinafter Merck Stip. Judgment], https:/www.iowaattorneygeneral.gov/ media/cms/Vioxx_Consent_Judgment_2323D7AEA24ED.pdf.

155. See id. at 6 . 
much time passed after submission. ${ }^{156}$ Through the settlement agreement, the AGs effectively switched a voluntary review procedure to a mandatory one, which is a power the FDA does not have due to potential First Amendment constraints. ${ }^{157}$

Following the Vioxx settlement, a multi-state group of AGs entered into a similar settlement with Pfizer for $\$ 60$ million related to its marketing of Celebrex and Bextra. ${ }^{158}$ As with the Vioxx settlement, the agreement included a provision that granted the AGs the power to enforce violations of FDA regulations, and it required that Pfizer submit all television advertising campaigns for any Pfizer prescripton drug or biological product to the FDA for pre-review. ${ }^{159}$ However, the agreement provided that in the event the FDA did not respond in 45 days Pfizer could run the advertisement after contacting the Multistate Executive Committee of AGs and informing them they have not received feedback from the FDA. ${ }^{160}$ This provided Pfizer with the ability to eventually run the advertisements in cases where the FDA did not respond, but it also provided the AGs an ability to monitor the promotional pieces as Pfizer was required to include all materials submitted to the FDA regarding its requested review with the notice to the AGs. ${ }^{161}$

156. See id.

157. See 21 U.S.C. § 352(n) (2012). The agreement also imposed additional disclosure requirements for Continuing Medical Education presenters who have had a "promotional relationship" with Merck, and it imposed additional restraints on individuals who could serve on external Drug Safety Monitoring Boards that review Merck safety studies. The requirements went beyond the usual financial conflicts and included items on vague potential biasing conflicts such as "intellectual conflict" or "career involvement" with the product under study. Finally, the agreement imposed additional requirements for an individual to be identified as an author in a manuscript for a Merck-sponsored clinical trial. To prevent the "ghostwriting" of journal articles, the agreement provided that the author of an article must have made "substantial contribution to the conception and design, or acquisition of data, or analysis and interpretation of data." Merck Stip. Judgment, supra note 154 , at $6-10$.

158. See Press Release, Or. Dep't of Justice, Or. Office of the Att'y Gen., AG Myers Files Judgment Against Pfizer for $\$ 60$ Million Concerning It’s Market of Drugs Celebrex \& Bextra (Oct. 22, 2008) [hereinafter Oregon AG Pfizer Press Release], http://www.doj.state.or.us/releases/pages/ 2008/rel102208.aspx (last visited Oct. 7, 2016). The agreement also included disclosure requirements for CME speakers and it prevented the "[g]host writing" of articles and studies, "[u]sing 'mentorships' to pay physicians for time spent with Pfizer sales reps," "[u]sing grants to encourage use of Pfizer products," "[u]sing sales personnel to make grant decisions that are supposedly unrelated to ... marketing," and "[u]sing patient testimonials to misrepresent a drug's efficacy.” See id.; Stipulated General Judgment, at \ 15-16, 18, 29-30, Oregon ex rel. Myers v. Pfizer Inc., No. 08C23533 (Or. Cir. Ct. Oct. 22, 2008) [hereinafter Pfizer Stip. Judgment], http://www.doj.state.or.us/releases/pdf/pfizer_stip_judg_complaint.pdf.

159. See Pfizer Stip. Judgment, supra note 158, at 98.

160. See id.

161. See id. 
The agreement also sought to regulate possible off-label marketing, an area of focus in future multi-state settlements. It prevented the use of samples to encourage off-label use. ${ }^{162}$ It also prohibited Pfizer from providing any incentives to its sales force for increasing the off-label use of a product, and it prohibited the distribution of articles and studies from scientific or medical journals ("reprints") discussing off-label uses in a promotional manner. ${ }^{163}$ In addition, the agreement included specific guidelines on the appropriate use and required contents of reprints. ${ }^{164}$

AGs expanded their off-label restrictions in a \$100 million multistate settlement with Abbott regarding its marketing of Depakote in 2012. ${ }^{165}$ The agreement specifically prohibited Abbott from promoting Depakote for off-label uses. ${ }^{166}$ It provided specific guidelines on how Abbott could respond to an unsolicited request by a physician about an off-label use. ${ }^{167}$ Sales personnel could only respond by informing the physician of the presence or absence of published studies concerning the off-label topic or acknowledging whether the topic is an area of research, and by offering to request on behalf of the physician that medical information be sent out as follow-up. ${ }^{168}$ The agreement also restricted the type of medical information such as reprints of articles that Abbott could distribute for these responses, and sales personnel were prevented from offering any opinions about or summarizing any off-label information. ${ }^{169}$ In addition, reprints containing information on an offlabel use could only be sent out by scientifically-trained personnel. ${ }^{170}$ While many of these requirements are recommendations in the FDA Guidance Documents on responding to unsolicited requests for off-label

\footnotetext{
162. See id. at 927.

163. See id. at ๆף 21-26; see also Oregon AG Pfizer Press Release, supra note 158.

164. See Pfizer Stip. Judgment, supra note 158, at 9ा 23-24. The agreement did provide Pfizer a mechanism to modify the off-label requirements regarding the use of reprints if the FDA were to issue final guidance documents that materially conflicted with the agreement. See id. at 925.

165. Press Release, Iowa Dep’t of Justice, Iowa Office of the Att'y Gen., Miller, State Attorneys General Reach \$100 Million Settlement over Off-Label Marketing of Prescription Drug Depakote (May 7, 2012), https://www.iowaattorneygeneral.gov/newsroom/miller-state-attorneysgeneral-reach-100-million-settlement-over-off-label-marketing-of-prescript/ (last visited Oct. 7,

166. Consent Judgment at 9 4.2, State ex rel. Miller v. Abbott Labs., No. CE 71444 (Iowa Dist. Ct. May 7, 2012), https://www.iowaattorneygeneral.gov/media/cms/Abbott_consent_ 398429BDF1CD9.pdf.

167. Id. at 9 ๆ $4.10-4.14$.

168. Id. at १ा 4.13-4.14.

169. Id. at भा 4.15-4.17.

170. Id. at 94.17 .
} 2016). 
information ${ }^{171}$ and reprints, ${ }^{172}$ the restrictions on speech for sales personnel go beyond any FDA recommendation or requirement. ${ }^{173}$

It appears unlikely that the FDA could enforce the restrictions on speech and the absolute prohibition on off-label promotion found in the Depakote settlement. In United States v. Caronia, the Second Circuit held that the First Amendment prohibits the government from prosecuting a drug manufacturer or individual solely on the basis of truthful speech. ${ }^{174}$ The FDA subsequently attempted to limit the applicability of Caronia to the particular facts and circumstances of that case, but recently, a federal district court in New York held that the First Amendment precludes the government from using the FD\&C Act to prohibit and criminalize truthful, non-misleading off-label speech. ${ }^{175}$ The court rejected the FDA's attempts to "marginalize the holding” in Caronia, and it declined to limit Caronia's holding to only reactive statements made by non-sales personnel. ${ }^{176}$ It was the court's "considered and firm view" that the FDA may not bring a misbranding action based on truthful non-misleading promotional speech alone. ${ }^{177}$

With these multi-state UDAP settlement agreements, AGs have expanded their enforcement powers into the FDA's realm and imposed regulatory demands on pharmaceutical manufacturers that go beyond the scope of the FDA's authority and may violate the First Amendment. Creating additional burdens above FDA regulations may not improve

171. See FDA, Guidance for Industry: Responding to Unsolicited Requests for Off-Label Information About Prescription Drugs and Medical Devices (Draft Guidance) 6-12 (2011), http://www.fda.gov/downloads/drugs/guidancecomplianceregulatoryinformation/guidances/ ucm285145.pdf.

172. See FDA, Guidance for Industry: Distributing Scientific and Medical Publications on Unapproved New Uses — Recommended Practices (Revised Draft Guidance) 7-17 (2014) [hereinafter FDA, Good Reprint Practices], http://www.fda.gov/downloads/drugs/guidancecomplianceregulatoryinformation/guidances/ucm387 652.pdf.

173. A similar multi-state settlement agreement was reached with Janssen/Johnson \& Johnson for its alleged deceptive marketing of Risperdal. The agreement prevented off-label promotion and restricted sales personnel's ability to respond to unsolicited requests for information about off-label uses. See Press Release, Vt. Office of the Att'y Gen., Attorney General Sorrell Announces Johnson \& Johnson to Pay Vermont \$4.1 Million as Part of Landmark Settlement (Aug. 30, 2012), http://ago.vermont.gov/focus/news/attorney-general-sorrell-announces-johnson-and-johnson-to-payvermont-4.1-million-as-part-of-landmark-settlement.php; see also Final Judgment and Consent Decree at 8-14, State v. Janssen Pharm. Inc., No. 620-8-12 WNCV (Vt. Super. Ct. Aug. 30, 2012), http://ago.vermont.gov/assets/files/12\%2008\%2030\%20Risperdal\%20Final\%20Judgment\%20and\% 20Consent\%20Decree\%20RKriger.pdf.

174. 703 F.3d 149, 168-69 (2d Cir. 2012).

175. See Amarin Pharma, Inc. v. FDA, 119 F. Supp. 3d 196, $223-28$ (S.D.N.Y. 2015).

176. See id. at 225.

177. See id. at 224. 
public health. For instance, while the broad restrictions on the dissemination of off-label information contained in some of these agreements are focused on punishing a company and preventing them from profiting from proactive off-label promotion, they generally fail to consider the value that certain patient groups place on the distribution of such off-label information. Off-label prescribing is common in medicine and it is often essential to giving patients optimal care. Some patient groups, such as children and individuals with rare diseases, rely heavily on off-label prescriptions due to the difficulty of studying and obtaining an FDA approved indication for them. In the area of oncology, it is estimated that between $50 \%$ and $75 \%$ of all cancer treatments are prescribed off-label, ${ }^{178}$ and in pediatrics, around $80 \%$ of the prescriptions are off-label. ${ }^{179}$

The FDA has acknowledged that "the public health may benefit when health care professionals receive truthful and non-misleading scientific or medical publications on unapproved new uses[,]" and it "recognizes the value to health care professionals of truthful and nonmisleading scientific or medical publications on unapproved new uses." ${ }^{180}$ Due to the complexity of the issues involved, the FDA has wrestled with trying to come up with the right balance for years. It seems unlikely that the FDA's mission is furthered by AGs restricting and penalizing pharmaceutical companies.

\section{Regulating Nursing Home Staffing}

AG use of UDAPs to regulate already-regulated industries extends to other businesses that comply with state and federal regulations. As noted earlier, in Pennsylvania, then-AG Kathleen Kane brought an action against a group of skilled nursing facilities (SNF) over staffing levels under the Pennsylvania Unfair Trade Practices and Consumer Protection Law (UTPCPL). ${ }^{181}$ She did so at the prompting of DC-based plaintiffs' law firm Cohen Milstein Sellers \& Toll PLLC, which used the state's broad subpoena power to require the facilities to produce information on

178. See Vicki W. Girard, Punishing Pharmaceutical Companies for Unlawful Promotion of Approved Drugs: Why the False Claims Act Is the Wrong Rx, 12 J. HEalth CaRE L. \& POL'Y 119, 131 (2009).

179. See James O’Reilly \& Amy Dalal, Off-Label or Out of Bounds? Prescriber and Marketer Liability for Unapproved Uses of FDA-Approved Drugs, 12 ANNALS HEALTH L. 295, 298 (2003).

180. See FDA, GoOd REPRINT PRACTICES, supra note 172, at 6.

181. See Kat Greene, Nursing Home Operators Blast Pa. AG's Hire of Cohen Milstein, LAw360 (Oct. 1, 2015), http://www.law360.com/articles/710002/nursing-home-operators-blast-paag-s-hire-of-cohen-milstein. 
the number of residents and staffing of each facility ${ }^{182}$ even before filing suit on June 30, 2015. ${ }^{183}$ The targets of this litigation include a half dozen or more nursing home chains representing about " $50 \%$ of the licensed beds in for-profit nursing homes in Pennsylvania."184 The Commonwealth's complaint seeks a civil penalty for each violation of the UTPCPL and, when the alleged violations involve individuals over 65 years of age, the civil fine rises from $\$ 1,000$ per violation to $\$ 3,000$ per violation. ${ }^{185}$

Pennsylvania's Department of Health (PA DOH) regulates staffing in SNFs. ${ }^{186}$ The PA DOH has adopted specific regulations governing nursing staff levels and the quality of care at SNFs. ${ }^{187}$ PA DOH regularly inspects SNFs to ensure that staffing regulations and care requirements are being met and is vested with the exclusive authority to bring actions or raise staffing levels where necessary. ${ }^{188}$ Pennsylvania law authorizes PA DOH to bring enforcement actions in the name of the Commonwealth for an injunction or other process restraining or prohibiting a healthcare provider from engaging in an activity in violation of the provisions of the Act or its implementing regulations. ${ }^{189}$ In addition, $\mathrm{PA} \mathrm{DOH}$ is the state agency responsible for ensuring that SNFs in Pennsylvania meet federal conditions for participation in both the Medicare and Medicaid programs. ${ }^{190}$ As part of this responsibility, PA DOH inspects each SNF at least annually and in response to complaints, and then must certify to the federal Centers for Medicare and Medicaid Services (CMS) that each SNF complies with the federal conditions for participation, including meeting federal staffing requirements. ${ }^{191}$

The nursing facilities argued in Pennsylvania Commonwealth Court, an intermediate appellate court, that the AG overstepped her authority by

\footnotetext{
182. See id.

183. Complaint and Petition for Injunctive Relief, Commonwealth v. Golden Gate Nat'l Senior Care LLC, No. 336 MD 2015 (Pa. Commw. Ct. June 30, 2015) [hereinafter Complaint and Petition].

184. Petitioners' Brief, supra note 87, at 5.

185. Complaint and Petition, supra note 183, at 91.

186. See Pa. Dep't of Health, Health Facilities Licensing, PA.GOV, http://www.health.pa.gov/facilities/Licensees/Healthcare\%20Facilities\%20Licensing/Pages/default.a spx\#.V8cR8I-cHmI (last visited Oct. 7, 2016) (indicating that Pennsylvania’s Department of Health regulates Pennsylvania nursing home compliance with federal and state regulations).

187. Petitioners’ Brief, supra note 87, at 13 (citing 28 PA. CODE §§ 201, 211 (2016)).

188. See 35 Pa. Stat. And Cons. Stat. AnN. § 448.813(a) (West 2003 \& Supp. 2014); 28 Pa. CODE §§ 201.2, 211.12(l) (2016); 42 U.S.C. §§ 1395aa, 1395i-3(g), 1396r(g) (2012).

189. 35 PA. STAT. AND CONS. STAT. ANN. § 448.817(a) (West 2003 \& Supp. 2014).

190. See 42 U.S.C. §§ 1395aa, 1395i-3g, 1396a, 1396r (2012); 55 PA. CODE § 1187.21 (2016).

191. See supra note 190 .
} 
"attempt[ing] to impose new and unapproved staffing standards on SNFs without notice and comment" and challenged the AG's authority to contract out enforcement power to private lawyers. ${ }^{192}$ In seeking a preliminary injunction against the state, the facilities stated that they expected the AG and the state's outside counsel to seize upon general statements the facilities made about providing for the needs of nursing home residents to allege that they engaged in deceptive marketing practices under the UTPCPL. ${ }^{193}$ The facilities also stated that they anticipate that the AG would then attempt to use the UTPCPL to "establish a new minimum staffing requirement in Pennsylvania of 2.8 to 3.2 hours of nursing aide staff per patient per day, which conflicts with PA DOH's minimum staffing requirement of 2.7 hours of nursing care per resident per day.”194

In January 2016, however, the Commonwealth Court ruled that the Pennsylvania AG's office could use the state's UDAP law to address advertisements or other representations about nursing home staffing levels, "whether in accord with those required by statute or regulation or not."195

4. Retroactively Defining Unfairness with Respect to Lending Practices

As the history of UDAP laws shows, when Congress enacted the Federal Trade Commission Act, upon which state laws were based, legislators were concerned that the law should provide businesses with advance notice as to the types of conduct that is unfair or deceptive, particularly if they are to be subject to a civil penalty. ${ }^{196}$ An example involving the mortgage lending industry shows that, under UDAP laws, businesses may be exposed to UDAP liability even when a practice was permitted and widespread at the time, but later became viewed as unfair.

In 2007, Massachusetts AG Martha Coakley brought an action against Fremont Investment \& Loan alleging that its residential mortgage lending practices violated Massachusetts' unfair or deceptive acts or practices statute, known as Chapter 93A. ${ }^{197}$ The AG argued that

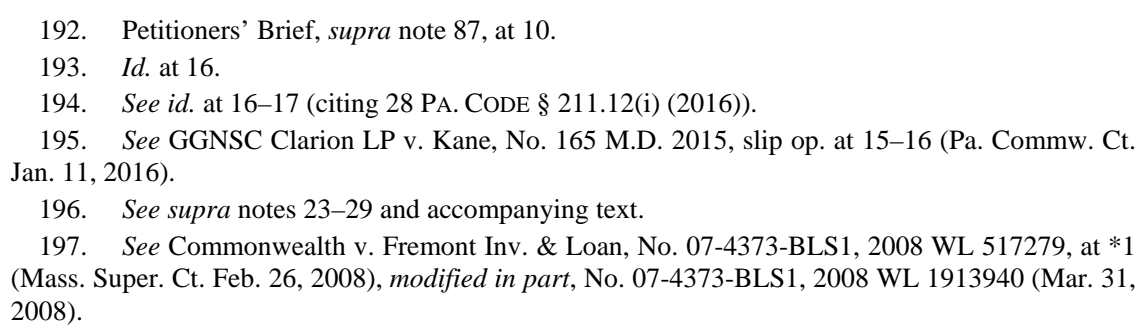


subprime loans were presumptively unfair and sought a preliminary injunction that would bar Fremont from foreclosing on certain loans originating between 2004 and 2007 without the written consent of the AG. ${ }^{198}$ Fremont opposed the preliminary injunction and argued that it had complied with all applicable laws and was truthful in all its representations to borrowers. ${ }^{199}$

The trial court found no evidence that Fremont made any false representations to the borrowers about the terms of the loans or that Fremont knew of or should have known of any exaggeration of the borrower's income. ${ }^{200}$ The court acknowledged that the loans did not violate any state or federal lending law, or industry standard, in effect at the time of origination. ${ }^{201}$ In fact, Fremont's lending practices were typical of the industry. ${ }^{202}$ The trial court, nonetheless, held that Fremont's subprime loans were presumptively structurally unfair under Massachusetts' UDAP statute and granted the preliminary injunction. ${ }^{203}$ It did so by applying the "spirit" of a separate statute applicable only to high-cost loans to all home loans. ${ }^{204}$

The court reasoned that the concept of unfairness is not fixed in "stone" or "limited to conduct that is unlawful under the common law or prior statutes." 205 Rather, the court found that unfairness is "forever evolving" so as to "reflect what we have learned to be unfair from our experience." 206 "As the mortgage market changes, so, too, must the understanding of what lending conduct is unfair."207

The court recognized that the Fremont loans were not generally viewed as unfair at the time they originated. ${ }^{208}$ Yet, it justified its retrospective application of unfairness by finding that Fremont had fair warning about the dangers of subprime loans due to non-binding federal agency guidelines on subprime lending and high loan-to-value loans. ${ }^{209}$ The rest of the industry, however, did not view such loans as improper.

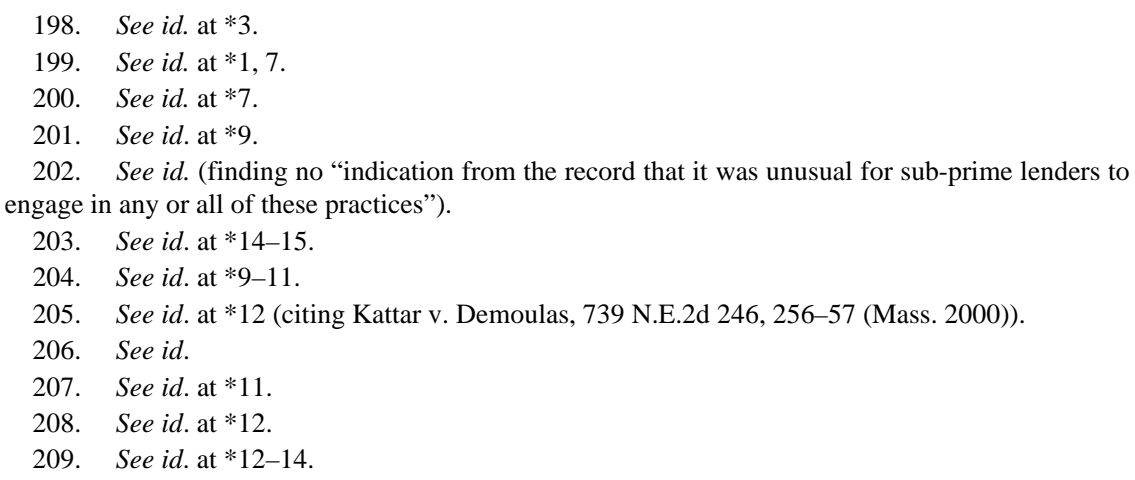


And even as the court found that the legislature could not have "imagine[d]" the risk posed by subprime loans, legislators had access to many of the referenced guidance documents when it drafted the law that applied only high-cost loans. ${ }^{210}$

After the Supreme Judicial Court of Massachusetts upheld the trial court's injunction, ${ }^{211}$ Fremont and the AG reached a \$10 million settlement. ${ }^{212}$ The settlement included \$8 million in consumer relief, \$1 million in civil penalties, and $\$ 1$ million in costs, including attorneys' fees. ${ }^{213}$ The agreement also secured an injunction affording state officials the opportunity to review any of Fremont's 2,200 Massachusetts mortgages before the initiation of foreclosure proceedings even if the loan had been transferred to another holder. ${ }^{214}$

\section{Aggregating "Per Violation" Civil Penalties}

UDAP laws provide a means for AGs to protect the rights of consumers by seeking injunctions to stop unfair or deceptive business practices before they cause harm and, where consumers have lost money, obtain restitution for them. These laws also authorize AGs to request that a court punish companies that have violated the law and deter others from engaging in similar conduct by imposing civil penalties.

In some states, all that an AG must show to establish a violation of a UDAP is that a business practice had the tendency to deceive or was capable of misleading someone. ${ }^{215}$ A violation may occur even if the business did not intend to deceive the public, consumers were not misled, and there was no actual loss. Most UDAP laws allow the AG to seek,

\footnotetext{
210. See id. at *11.

211. See Commonwealth v. Fremont Inv. \& Loan, 897 N.E.2d 548, 551 (Mass. 2008).

212. See Press Release, Mass. Office of the Att'y Gen., Attorney General Martha Coakley Reaches \$10 Million Settlement with Subprime Lender Fremont Investment and Loan (June 9, 2009), http://www.mass.gov/ago/news-and-updates/press-releases/2009/ag-coakley-reaches-10msettlement-with.html.

213. See id.

214. See id.

215. See, e.g., D.C. CODE ANN. § 28-3904 (West 2015) (stating that a person violates the law "whether or not any consumer is in fact misled, deceived or damaged thereby"); MD. CODE ANN., CoM. LAW §§ 13-301(1), 13-302 (West 2013) (providing that the capacity or tendency to deceive establishes a violation "whether or not any consumer in fact has been misled, deceived, or damaged as a result of that practice"); California ex rel. Lockyer v. Fremont Life Ins. Co., 104 Cal. App. 4th 508, 516-17 (Cal. Ct. App. 2002) (finding that the "test is whether the public is likely to be deceived ... even if no one was actually deceived, relied upon the fraudulent practice or sustained any damage.”); State ex rel. McLeod v. Brown, 294 S.E.2d 781, 783 (S.C. 1982) (finding a "tendency to deceive and mislead" without proof of actual deception is sufficient to establish liability (quoting U.S. Retail Credit Ass'n v. FTC, 300 F.2d 212, 221 (4th Cir. 1962)).
} 
and the court to impose, a civil penalty for any violation of the act. About twenty state laws require evidence that a business knowingly, willfully, or intentionally engaged in a deceptive practice before imposing civil penalties, ${ }^{216}$ though in practice, this culpability requirement often receives little consideration.

Civil penalties range from up to $\$ 1,000$ to up to $\$ 50,000$ per violation. $^{217}$ About half of the states set the maximum civil penalty in the $\$ 1,000$ to $\$ 5,000$ range, ${ }^{218}$ an amount that can still reach an extraordinary sum when aggregated per violation. About the same number of states have maximum penalties set at $\$ 10,000,{ }^{219}$ or more. ${ }^{220}$

216. See, e.g., Ala. CODE § 8-19-11(b) (2002); ARIZ. REv. STAT. AnN. § 44-1531(A) (2013); Del. Code AnN. tit. 6, §§ 2522(b), 2533(e) (West 2011 \& Supp. 2016); Fla. STAT. AnN. § 501.2075 (West 2010); IND. CODE ANN. § 24-5-0.5-4(g) (West 2006 \& Supp. 2013); MASs. GEN. LAWS ANN. ch. 93A, § 4 (West 2006); Miss. CodE ANN. § 75-24-19(1)(b) (West 1999); MonT. CODE ANN. § 30-14-111(1) (2013); NEV. REV. STAT. ANN. § 598.0999(2) (West 2014); N.M. STAT. ANN. § 57-12-11 (West 2003); OR. Rev. StAT. ANN. § 646.642(3) (West 2011); 73 PA. STATE AND CONS. STAT. ANN. § 201-8(b) (West 2008); S.C. CODE ANN. § 39-5-110(a) (1985); VA. CoDE ANN. $\S$ 59.1-206(A) (West 2011); Wyo. StAT. AnN. § 40-12-113(c) (West 2007). See also La. STAT. ANN. § 51:1407(B) (2002 \& Supp. 2014) (“intent to defraud”); ME. REV. STAT. ANN. tit. 5, § 209 (West 2013) ("intentional”); MICH. CoMP. LAWS ANN. § 445.905(1) (West 2011) (“persistent and knowing”); S.D. CODIFIED LAWS § 37-24-27 (2004) (“intentionally”).

217. See 815 Ill. Comp. StAT. ANN. 505/7(b) (West 2008) (authorizing civil penalty not to exceed $\$ 50,000$, or $\$ 50,000$ per violation when court finds an intent to defraud); D.C. CODE ANN. § 28-3905(i)(3) (West 2015) (\$1,000).

218. See Ala. Code § 8-19-11(b) (2002) (\$2,000); CAL. Bus. \& PROF. CODE § 17206(a) (West 2008 \& Supp. 2014) (\$2,500); Colo. REv. STAT. ANN. § 6-1-112(1)(a) (West Supp. 2013) (\$2,000); D.C. CodE ANN. § 28-3905(i)(3) (West 2015) (\$1,000); GA. CODE ANN. § 10-1-397(b)(2)(B) (West Supp. 2013) (\$5,000); IDAHO CODE ANN. § 48-606(1)(e) (West 2006) (\$5,000); IND. CODE ANN. § 24-5-0.5-4(g) (West 2006 \& Supp. 2013) (\$5,000); LA. STAT. ANN. § 51:1407(B) (Supp. 2014) $(\$ 5,000)$; MD. CODE ANN., COM. LAW. § 13-410(a) (West 2013) (\$1,000); MASS. GEN. LAWS ANN. ch. 93A, § 4 (West 2006) (\$5,000); Mo. ANN. STAT. § 407.020(6) (West 2011 \& Supp. 2016) $(\$ 1,000) ;$ Neb. Rev. Stat. AnN. § 59-1614 (West 2009) (\$2,000); Nev. Rev. Stat. AnN. § 598.0999(2) (West 2014) (\$5,000); N.M. STAT. ANN. § 57-12-11 (West 2003) (\$5,000); N.Y. GEN. Bus. LAW § 349(h) (McKinney 2012) (\$1,000); N.C. GEN. STAT. ANN. § 75-15.2 (West 2012) (\$5,000); N.D. CENT. CODE ANN. § 51-15-07 (West 2008) (\$1,000); 73 PA. STAT. AND CONS STAT. ANN. § 201-8(b) (West 2008) (\$1,000); S.C. CODE ANN. § 39-5-110(a) (1985) (\$5,000); S.D. CODIFIED LAWS § 37-24-27 (2004) (\$2,000); TENN. CODE ANN. § 47-18-108(c) (West 2002) (\$2,000); VA. CODE ANN. § 59.1-206(A), (C) (West 2011) (\$1,000 for violation, \$2,500 for willful violation).

219. See, e.g., ARIZ. Rev. StAT. AnN. § 44-1531(A) (2013); ARK. Code ANN. § 4-88-113(c) (West 2004); DEL. CODE ANN. tit. 6, § 2522(b) (West 2011 \& Supp. 2016); Fla. STAT. ANN. § 501.2075 (West 2010); HaW. ReV. Stat. AnN. § 480-15.1 (West 2008); Kan. Stat. AnN. § 50636(a) (2005); ME. REV. STAT. ANN. tit. 5, § 209 (West 2013); MISs. CODE ANN. § 75-24-19(1)(b) (West 1999); MonT. CODE ANN. § 30-14-142(2) (2013); N.H. REV. STAT. ANN. § 358-A:4(III)(b) (2009); N.J. STAT. ANN. § 56:8-13 (West 2012); OKLA. STAT. ANN. tit. 15, § 761.1(C) (West 2013); VT. STAT. ANN. tit. 9, § 2458(b)(1) (West 2007 \& Supp. 2013); Wis. StAT. ANN. § 100.26 (West 2010); WYO. STAT. ANN. § 40-12-113(c) (West 2007).

220. See, e.g., ALASKa StAT. ANN. § 45.50.551(b) (West 2007) (\$25,000); 815 Ill. Comp. STAT. ANN. 505/7(b) (West 2008) (\$50,000); IOWA CODE ANN. § 714.16(7) (West 2003) (\$40,000); Mich. COMP. LAWS § 445.905(1) (2011) (\$25,000); MinN. STAT. ANN. § 8.31(3) (2013) (\$25,000); 
In addition, some states provide for higher civil penalties when a violation involves individuals who are elderly or disabled, ${ }^{221}$ and some provide for additional penalties for repeat offenders. ${ }^{22}$

Most UDAP laws provide no guidance as to when a civil penalty should be on the smaller or larger end of the permissible range. Complaints often seek the maximum fine permitted under the law. The arbitrariness of the amount of the civil penalty is compounded by how courts calculate the number of violations. AGs often seek "per violation" civil penalties based on every prescription filled, letter sent, product sold, or advertisement published or aired for the longest period allowed under the statute of limitations. As a result, businesses are exposed to extraordinary penalties for a single action even when the conduct did not mislead anyone or cause an economic loss.

These problems do not arise under the FTC Act, the model for many UDAP laws. Federal law authorizes the FTC to bring an action against a business that has engaged in deceptive practices and obtain a cease-anddesist order. The FTC can also require businesses that violate the FTC Act to provide consumers with refunds, pay damages, or provide other consumer redress. ${ }^{223}$ For example, a company accused of selling bogus weight loss pills and using fake celebrity endorsements recently agreed to pay $\$ 43$ million to settle the FTC's claims, which will go into a consumer redress fund. ${ }^{224}$

In addition, the FTC can seek civil penalties of up to $\$ 16,000$ per violation when a business violates a consent agreement (under which it agreed, without admitting liability, to stop a practice of concern to the Commission) or continues a practice after the Commission finds it is deceptive and issues a cease-and-desist order. ${ }^{225}$ The Commission may

OHIo Rev. Code AnN. § 1345.07(D) (West 2004 \& Supp. 2014) (\$25,000); OR. Rev. STAT. AnN. § 646.642 (West 2011) (\$25,000); TEX. Bus. \& CoM. CODE ANN. § 17.47(c) (West 2011) (\$20,000).

221. See, e.g., CAL. Bus. \& PROF. CODE § 17206.1(a)(1) (West 2008 \& Supp. 2014) (additional $\$ 2,500$ civil penalty for acts against elderly or disabled); CoLO. REv. STAT. ANN. § 6-1-112 (2002 \& Supp. 2013) (penalty increased from $\$ 2,000$ to $\$ 10,000$ for violations against the elderly); FLA. STAT. ANN. § 501.2077 (West 2010 \& Supp. 2014) (penalty increased from $\$ 10,000$ to $\$ 15,000$ for violations against the elderly); 815 ILL. COMP. STAT. ANN. 505/7(c) (West 2008) (additional $\$ 10,000$ penalty for violation against the elderly); IOWA CODE ANN. § 714.16A (West 2003 \& Supp. 2014) (additional $\$ 5,000$ penalty for violation against the elderly).

222. See, e.g., N.J. STAT. ANN. § 56:8-13 (West 2012) (penalty increased from $\$ 10,000$ for first violation to \$20,000 for subsequent violations); MD. CODE ANN., COM. LAW § 13-410 (West 2013) ( $\$ 1,000$ per violation increased to $\$ 5,000$ per violation for subsequent violations).

223. See 15 U.S.C. § 57b(b) (2012).

224. See FTC v. Sale Slash, LLC, No. CV 15-3107 PA (AJWx), at 27, 36 (C.D. Cal. Feb. 1, 2016) (Stipulated Order for Permanent Injunction \& Monetary Judgment).

225. See 15 U.S.C. § 45(l) (2012); 16 C.F.R. § 1.98(c) (amended on Aug. 1, 2016 by 81 Fed. Reg. 42478) (adjusting civil penalty from $\$ 10,000$ provided by FTC Act to $\$ 40,000$ per violation). 
also seek civil penalties from businesses that have not entered a consent agreement or received a cease-and-desist order if the FTC first provides that business with a copy of the Commission determination in a similar case finding the act or practice unfair or deceptive. ${ }^{226}$ The public policy underlying this process recognizes that "unfair" and "deceptive" are vague terms and that it is improper to punish a business without first giving it notice that its conduct violates the law. Civil penalties, under federal law, are reserved for situations in which the violator had "actual knowledge that such act or practice is unfair or deceptive and is unlawful.,"227

There is no such process before an AG decides to bring an action under UDAP laws. Rather, in nearly every state, the AG can immediately seek civil penalties, without first providing notice of a violation $^{228}$ or seeking an injunction or other relief for consumers. ${ }^{229}$ As discussed earlier, when the state litigates through a contingency-fee arrangement, the private lawyers representing the state have an incentive to seek the maximum penalty in every case, regardless of whether such a fine is appropriate and in the public interest. In addition, due to the lack of notice as to the legality of conduct under UDAPs, the unpredictability of the potential penalty, and the lack of proportionality in many cases between the size of the fine and the conduct or harm, these civil penalties raise serious constitutional concerns. ${ }^{230}$ They are ripe for challenge under the Due Process Clause and Excessive Fines Clauses of the U.S. Constitution and similar state constitutional safeguards. ${ }^{231}$

226. See FTC, A Brief Overview of the Federal Trade Commission's Investigative and Law Enforcement Authority, FTC.GOV (July 2008), https://www.ftc.gov/about-ftc/what-wedo/enforcement-authority (last visited Oct. 7, 2016).

227. 15 U.S.C. § 45(m)(1)(B)(2) (2012 \& Supp. 2016).

228. A handful of states require the state AG to contact a business before filing a UDAP enforcement action, but permit the AG to seek civil penalties even if the business offers to immediately address the concern. See, e.g., ME. Rev. StAT. AnN. tit. 5, § 209 (West 2013) (requiring AG to provide a person with at least 10 days' notice of the intended action, and "give the person an opportunity to confer with” the AG); N.Y. GEN. BUS. LAW § 349(c) (McKinney 2012) (requiring AG to give business notice and "an opportunity to show in writing within five business days ... why proceedings should not be instituted[,]" unless AG finds notice "is not in the public interest”); TENN. CODE ANN. § 47-18-108(a)(2) (West 2002) (requiring ten days’ notice).

229. Rhode Island appears to be the only state that requires a violation of the terms of an injunction before imposing civil penalties. See 6 R.I. GEN. LAWS ANN. § 6-13.1-8 (West 2006).

230. See United States v. Bajakajian, 524 U.S. 321, 337, 340 (1998) (holding in the context of forfeiture that a fine is "punitive" in nature and is excessive where "grossly disproportional to the gravity of the defendant's offense" and "bears no articulable correlation to any injury suffered by the Government”).

231. See generally U.S. CHAMBER INST. FOR LEGAL REFORM, U.S. CHAMBER, CONSTITUTIONAL CONSTRAINTS: PROVISIONS LiMiting EXCESSIVE GOVERNMENT Fines (Oct. 27, 2015), http://www.instituteforlegalreform.com/research/constitutional-constraints-provisions- 
1. Multi-Million Dollar Civil Penalty Without Deception or Harm in South Carolina

The previously discussed South Carolina case against Janssen for its marketing of Risperdal provides an example of the arbitrariness in how civil penalties can be calculated. It also illustrates the level of exposure companies can face when the aggregation of "per violation" penalties are combined with a low standard of proof. ${ }^{232}$ Under the South Carolina Unfair Trade Practices Act (SCUTPA), the AG is authorized to seek up to $\$ 5,000$ per violation upon a showing that the party knew or should have known that the conduct was unlawful. ${ }^{233}$ The AG is not required to prove that the company's statements were made with an intent to deceive, caused anyone any injury, or that anyone relied on these statements to impose a civil penalty, but only that the statements at issue have a "tendency to deceive." 234

The state, litigating through outside counsel, made two distinct claims under SCUTPA-(1) the Risperdal labeling itself was unfair and misleading because it did not include sufficient information on the risks associated with the drug; and (2) the dear doctor letter sent by the company to doctors about the drug was misleading. In making these claims, the AG relied on the previously discussed April 2004 FDA warning letter, which concluded that the dear doctor letter did not properly disclose the risks of hyperglycemia and diabetes associated with the drug. ${ }^{235}$ In response, the manufacturer sent a corrective letter to doctors acknowledging the omission. ${ }^{236}$

The trial court accepted the state's argument that the distribution to physicians of each sample box containing the allegedly deceptive labeling, each dear doctor letter, and each follow-up sales call after the dear doctor letter constituted a separate SCUTPA violation. ${ }^{237}$ The trial court imposed a \$300 civil penalty for each of 509,499 Risperdal sample

\footnotetext{
limiting-excessive-government-fines. See also Brief of the Chamber of Commerce of the United States as Amicus Curiae in Support of Petitioner, Ortho-McNeil-Janssen Pharm., Inc. v. South Carolina, No. 15-600, 2015 WL 8489380 (Dec. 9, 2015), cert. denied, 136 S. Ct. 824 (Jan. 11, 2016) (urging Court to grant certiorari to consider whether \$124 million civil penalty in UDAP action obtained by contingency fee lawyers representing state, without evidence of injury to public, violates Excessive Fines Clause).

232. See State ex. rel. Wilson v. Ortho-McNeil-Janssen Pharm., Inc., 777 S.E.2d 176, 192 (S.C. 2015).

233. S.C. CODE ANN. § 39-5-100 (1985).

234. State ex rel. Wilson, 777 S.E.2d at 193.

235. See id. at 187.

236. See id.

237. See id. at 203.
} 
boxes distributed in the state between 1998 and the date the lawsuit was filed on April 23, 2007 (\$152.8 million). ${ }^{238}$ It also imposed a \$4,000 civil penalty for each of 7,184 dear doctor letters sent to physicians in the state (\$28.7 million) and each of 36,372 follow-up sales calls made to doctors (\$145.5 million). ${ }^{239}$ The total civil penalty was reportedly the largest imposed under SCUTPA in state history. ${ }^{240}$

The South Carolina Supreme Court found the "per box" and "per sales call” civil penalty amounts excessive. It reduced these fines from $\$ 300$ to $\$ 100$ and $\$ 4,000$ to $\$ 2,000$, respectively, but offered little explanation for why its substituted amounts were reasonable, but the trial court's amounts were not. ${ }^{241}$ The court did not reduce the $\$ 4,000$ penalty for each dear doctor letter, calling the question of whether this fine is excessive a "close" one. ${ }^{242}$

In future cases, the South Carolina Supreme Court directed trial courts to consider a list of non-exclusive factors when assessing civil penalties under SCUTPA. These factors include:

(1) the degree of culpability and good or bad faith of the defendant; (2) the duration of the defendant's unlawful conduct; (3) active concealment of information by the defendant; (4) defendant's awareness of the unfair or deceptive nature of their conduct; (5) prior similar conduct by the defendant; (6) the defendant's ability to pay; (7) the deterrence value of the assessed penalties; and (8) the actual impact or injury to the public resulting from defendant's unlawful conduct. ${ }^{243}$

The court, however, did not discuss in depth how it weighed these factors to arrive at what it deemed to be a non-excessive fine.

Ultimately, the court concluded that the manufacturer, in an effort to increase sales, had given misleading information to doctors, warranting civil penalties. ${ }^{244}$ But the court acknowledged that the manufacturer's conduct "likely had little impact on the community of prescribing physicians." 245 The court recognized an "absence of significant actual

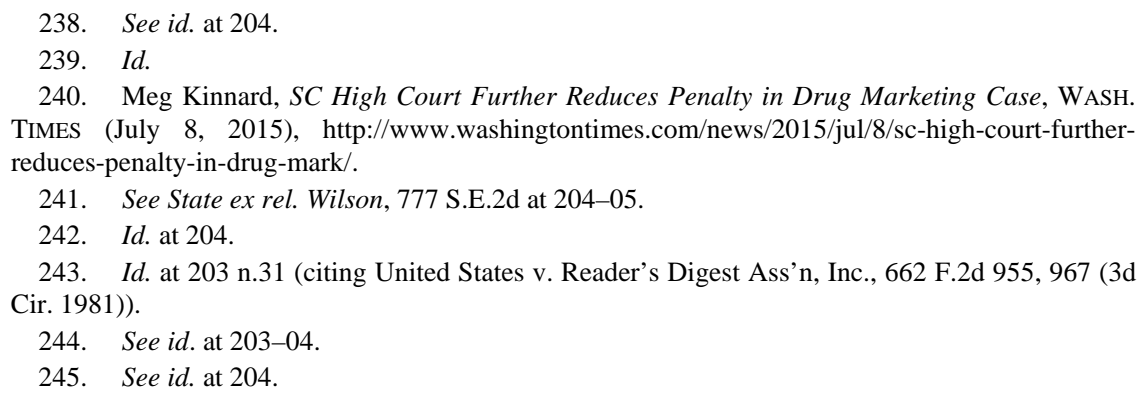


harm” to the public. ${ }^{246}$ It also found the trial court improperly included sample boxes that were outside the statute of limitations and reduced the violations for the sample boxes from 509,499 to 228,447. ${ }^{247}$

As a result, the South Carolina Supreme Court reduced the total combined civil penalty from \$327 million to \$124 million, declaring that by doing so it had resolved any due process concerns and the penalties were not excessive under the prohibition of excessive fines under the Eighth Amendment to the U.S. Constitution. ${ }^{248}$ The civil penalty imposed by South Carolina, however, was twenty-five times greater than the average state award under the settlement agreement with thirty-six states and the District of Columbia to resolve their UDAP claims regarding Risperdal marketing. ${ }^{249}$ The U.S. Supreme Court denied certiorari ${ }^{250}$ of an appeal raising the questions of whether a \$124 million civil penalty, without any showing of actual deception, reliance, or injury, violates the Excessive Fines Clause. ${ }^{251}$

\section{2. “Slash and Burn” Tactics in Mississippi Action}

In a similar action, Mississippi AG Jim Hood, working with plaintiffs' law firms (one of which was located in Texas but donated $\$ 75,000$ to his campaign), ${ }^{252}$ filed an action against Eli Lilly related to its marketing of Zyprexa, a drug in the same class as Risperdal, known as atypical antipsychotic drugs. While the FDA approved Zyprexa for treating serious psychiatric disorders, such as schizophrenia and bipolar disorder, the lawsuit alleged the company marketed it for unapproved uses and that it did not fully disclose potential risks, such as weight gain and diabetes. Nearly all other states had settled its claims with the drug maker by 2009, except Mississippi. ${ }^{253}$

\footnotetext{
246. See id.

247. See id. at 197-200, 204.

248. See id. at 205.

249. See id. at 206 n.33.

250. Ortho-McNeil-Janssen Pharm., Inc. v. South Carolina ex rel. Wilson, 136 S. Ct. 824 (Jan. 11, 2016) (mem.).

251. See Petition for Writ of Certiorari at 15-16, Ortho-McNeil-Janssen Pharm., Inc. v. South Carolina ex rel. Wilson, No. 15-600 (Nov. 5, 2015), 2015 WL 6866216, at*15-16. The appeal also raised the questions of whether a state violates the First Amendment by punishing a defendant for speech without showing a knowing or reckless falsehood, and whether federal law preempts state enforcement actions that seek to penalize a pharmaceutical company for actions comprehensively regulated by the FDA. See id. at 18.

252. See John O’Brien, Lilly Settles Ark. Suit Brought by Bailey Firm, LEgAL NEwSLine (Feb. 18, 2010), http://legalnewsline.pli-records-staging.locallabs.com/stories/510522422-lilly-settles-arksuit-brought-by-bailey-firm.
}

253. See In re Zyprexa Prods. Liab. Litig., 671 F. Supp. 2d 397, 407 (E.D.N.Y. 2009). 
The Mississippi Consumer Protection Act (MCPA) authorizes a civil penalty of up to $\$ 10,000$ for each knowing and willful violation. ${ }^{254}$ AG Hood requested that the court apply this maximum amount to each of almost one million estimated Zyprexa prescriptions in Mississippi. ${ }^{255}$ Attorneys for the state took the position that Mississippi was entitled to this amount without the need to show proof of reliance or causation, and irrespective of any costs or damages borne by the state. ${ }^{256}$

In December 2009, Judge Jack B. Weinstein of the U.S. District Court for the Eastern District of New York dismissed Mississippi's claim for statutory penalties under the MCPA, as well as all of the state's other claims but one. Judge Weinstein found that in order to appropriately assess a civil penalty, he would need more information about each prescription filled, such as whether it was for an approved or off-label use, whether the patient benefited from the medicine, and whether the patient experienced any of the potential side effects at issue. ${ }^{257}$ The state, however, had not offered such individual information, leading the court to find it impossible to fairly exercise its discretion to impose appropriate penalties. This type of assessment, Judge Weinstein added, would be beyond the resources of the court, given the individualized inquiry needed for hundreds of thousands of claimed violations. ${ }^{258}$

On the other hand, Judge Weinstein found that Lilly had "created a product with substantial benefits that even now-after many years of litigation, research, testing, and controversy-is still favored by many physicians and patients in Mississippi and elsewhere for some of the most serious psychological conditions that afflict millions of people worldwide." ${ }^{259}$

Judge Weinstein also recognized "serious constitutional ... questions" with the scale of recovery sought by Mississippi. ${ }^{260}$ He found that "Mississippi's requests for statutory penalties on a per-violation basis, in addition to actual damages sought, would result in a multibillion dollar cumulative penalty grossly disproportionate to both the injury Mississippi ha[d] suffered and the seriousness of Lilly's alleged misconduct.” ${ }^{261}$ These types of claims, which aggregate civil penalties

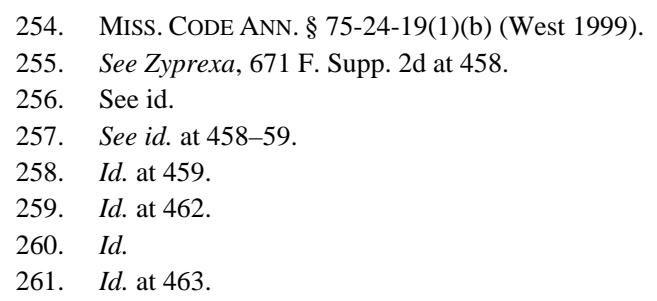


on a per violation basis, "could result in serious harm or bankruptcy for this defendant and the pharmaceutical industry generally."262 Judge Weinstein concluded:

For the legal system to be used for this slash-and-burn-style of litigation would arguably constitute an abuse of the legal process. Constitutional, statutory, and common law rights of those injured to seek relief from the courts must be recognized. But courts cannot be used as an engine of an industry's unnecessary destruction. ${ }^{263}$

Just two months after Judge Weinstein's ruling, Mississippi agreed to an \$18.5 million settlement of which \$3.7 million went to the state's outside counsel. ${ }^{264}$

\section{The "Pile on Effect"}

As atypical antipsychotic drug litigation shows, it is commonplace for businesses to face similar UDAP enforcement actions from multiple states or a coordinated multi-state AG action. Consumer class actions, sometimes brought by the same private lawyers who sue on behalf of state AGs, may seek treble damages and attorneys' fees. Individual lawsuits stemming from the same conduct may seek actual damages, statutory damages, and punitive damages. Businesses may also face claims brought by the federal government. The potential liability exposure for a single course of conduct is staggering.

For example, in litigation alleging Lilly improperly marketed Zyprexa discussed above, the pharmaceutical maker agreed to a \$62 million multi-state settlement with thirty-three state AGs to resolve UDAP claims. ${ }^{265}$ It then settled individually with the state AGs of Arkansas, Connecticut, Idaho, Mississippi, Montana, New Mexico, South Carolina, Utah, and West Virginia for roughly \$196 million. ${ }^{266}$ Lilly also settled the DOJ's off-label marketing allegations for \$1.415

\footnotetext{
262. Id.

263. Id. at 463-64.

264. See John O’Brien, Lilly Decides to Settle with AG Hood, LegAL NewsLine (Feb. 4, 2010), http://legalnewsline.com/stories/510522340-lilly-decides-to-settle-with-ag-hood.

265. Press Release, Iowa Dep't of Justice, Iowa Att'y Gen., States Reach Landmark Settlement with Eli Lilly \& Co. Over Marketing of Drug Zyprexa (Oct. 8, 2008), https://www.iowaattorneygeneral.gov/newsroom/states-reach-landmark-settlement-with-eli-lillyand-co-over-marketing-of-drug-zyprexa.

266. John O’Brien, Louisiana Settles with Eli Lilly, \$4M for Private Attorneys, LEGAL NEWSLine (Apr. 8, 2010), http://legalnewsline.com/stories/510522712-louisiana-settles-with-elililly-4m-for-private-attorneys.
} 
billion, ${ }^{267}$ and settled roughly 26,000 individual products liability suits for $\$ 1.2$ billion. ${ }^{268}$ In addition, Lilly faced a class action brought on behalf of third-party payor institutional plaintiffs, including pension funds, labor unions, and insurance companies that made outlays for Zyprexa prescriptions as well as several shareholder derivative actions. ${ }^{269}$

This form of cumulative litigation is not isolated to the pharmaceutical industry. Toyota faced a similar set of lawsuits in the unintended acceleration litigation. Toyota agreed to a \$29 million settlement with thirty state AGs to resolve UDAP claims, ${ }^{270}$ plus another \$16 million to settle UDAP claims brought by the Orange County, California District Attorney. ${ }^{271}$ The issue also generated a consumer class action lawsuit seeking economic losses on behalf of all vehicle

267. Press Release, Dep’t of Justice, Pharmaceutical Company Eli Lilly to Pay Record $\$ 1.415$ Billion for Off-Label Drug Marketing (Jan. 15, 2009), http://www.fda.gov/ICECI/Criminal Investigations/ucm260967.htm.

268. Erin Marie Daly, Lilly to Pay Conn. \$25M over Zyprexa Marketing, LAw360 (Sept. 29, 2009), http://www.law360.com/articles/125218/lilly-to-pay-conn-25m-over-zyprexa-marketing.

269. Erin Fuchs, Lilly, 3rd-Party Payors Reach \$4.5M Deal in Zyprexa Case, LAw360 (Jan. 12, 2012), http://www.law360.com/articles/299895/lilly-3rd-party-payors-reach-4-5m-deal-in-zyprexacase. Janssen/Johnson \& Johnson faced a similar set of lawsuits in the Risperdal litigation. Janssen agreed to a \$181 million settlement with thirty-seven AGs. Bryan Cohen, AGs Settle with Janssen for \$181M, LEGAL NEwsLine (Aug. 30, 2012), http://legalnewsline.com/stories/510527914-agssettle-with-janssen-for-181m. It settled Montana and Texas individually for \$5.9 million and \$61 million, respectively. Bryan Cohen, Montana Reaches \$5.9 Million Settlement with Janssen Over Risperdal, LEGAL NEWSLINE (Mar. 10, 2014), http://legalnewsline.com/stories/510517175-montanareaches-5-9-million-settlement-with-janssen-over-risperdal; see Bryan Cohen, Texas Will Receive \$61M in Risperdal Settlement, LEGAL NEWSLiNE (Mar. 10, 2012), http://legalnewsline.com/stories/ 510526789-texas-will-receive-61m-in-risperdal-settlement. The UDAP claims were only one part of the Texas settlement. Id. Jury verdicts were obtained in Arkansas ( $\$ 1.2$ billion false claims and UDAP), Louisiana (\$330 million false claims), South Carolina (\$327 million), and West Virginia (\$4.5 million), but with the exception of South Carolina in which the damages were reduced, all the jury verdicts were overturned. Ortho-McNeil-Janssen Pharm., Inc. v. State, 432 S.W.3d 563, 570, 580 (Ark. 2014); Caldwell v. Janssen Pharm., Inc., 144 So.3d 898, 901 (La. 2014); State ex rel. McGraw v. Johnson \& Johnson, 704 S.E.2d 677, 680 (W. Va. 2010); see supra notes 240-42 and accompanying text (discussing South Carolina litigation). Janssen also agreed to a \$2.2 billion multi-state and federal settlement to resolve civil and criminal allegations. Chris Dickerson, Risperdal Subject of \$2.2 Billion Settlement, LEGAL NEWSLiNe (Nov. 5, 2013), http://legalnewsline.com/stories/510516465-risperdal-subject-of-2-2-billion-settlement. Janssen also faced private lawsuits.

270. Bryan Cohen, Toyota Agrees to \$29 Million Multi-State Settlement, LEGAL NEWsLiNE (Feb. 15, 2013), http://legalnewsline.com/stories/510514715-toyota-agrees-to-29-million-multistate-settlement.

271. David McAfee, Toyota Pays \$16M to Settle Calif. DA’s Acceleration Suit, LAW360 (Apr. 5, 2013), http://www.law360.com/articles/430817/toyota-pays-16m-to-settle-calif-da-s-accelerationsuit. 
owners, which Toyota settled for an estimated $\$ 1.1$ billion. ${ }^{272}$ In addition, the automaker paid a $\$ 1.2$ billion penalty to the federal government, ${ }^{273}$ settled a shareholder class action for $\$ 25.5$ million, ${ }^{274}$ and settled around 340 personal injury/wrongful death suits for an undisclosed sum. ${ }^{275}$

Courts have recognized that punishing a business repeatedly for the same conduct raises significant constitutional concerns. ${ }^{276}$ None have yet addressed whether civil penalties imposed under UDAPs when combined with other government penalties and punitive damages in private lawsuits, or settlements of actions that contain a punitive element, cross this threshold.

272. Amended Economic Loss Master Consolidated Complaint, In re Toyota Motor Corp. Unintended Acceleration Marketing, Sales Practices, \& Prods. Liab. Litig., No. 8:10ML 02151 JVS (FMOx), 2010 WL 4257075 (C.D. Cal. Oct. 27, 2010); Order Granting Motion for Final Approval of Proposed Class Action Settlement, and Granting Motion for Attorneys' Fees, Reimbursement of Expenses, and Compensation to Named Plaintiffs, In re Toyota Motor Corp. Unintended Acceleration Marketing, Sales Practices, \& Prods. Liab. Litig., No. 8:10ML 02151 JVS (FMOx) (C.D. Cal. July 24, 2013); Bill Callahan \& Edvard Pettersson, Toyota Settlement of Acceleration Cases Wins Approval, BLOOMBERG (July 19, 2013), http://www.bloomberg.com/news/articles/201307-19/toyota-settlement-of-acceleration-cases-wins-approval.

273. Press Release, Dep’t of Justice, Justice Department Announces Criminal Charge Against Toyota Motor Corporation and Deferred Prosecution Agreement with \$1.2 Billion Financial Penalty (Mar. 19, 2014), https://www.justice.gov/opa/pr/justice-department-announces-criminal-chargeagainst-toyota-motor-corporation-and-deferred.

274. Ken Bensinger, Toyota Settles Shareholder Lawsuit Related to Sudden Acceleration, L.A. Times (Nov. 14, 2012), http://articles.latimes.com/2012/nov/14/business/la-fi-mo-toyotashareholder-lawsuit-20121114.

275. See Aebra Coe, Toyota Says It's Settled 338 Cases So Far in Acceleration MDL, Law360 (July 22, 2015), http://www.law360.com/articles/681915/toyota-says-it-s-settled-338-cases-so-farin-acceleration-mdl?article_related_content $=1$.

276. See, e.g., Dunn v. HOVIC, 1 F.3d 1371, 1385, 1391 (3d Cir.) (en banc) (instructing district courts to "determine whether a punitive award to a plaintiff in a particular case should be struck by carefully scrutinizing the 'punitive damages overkill' evidence submitted to them, both with respect to past awards actually paid by the defendant and the defendant's ability to satisfy future punitive damages awards"), modified in part, 13 F.3d 58 (3d Cir. 1993); Simpson v. Pittsburgh Corning Corp., 901 F.2d 277, 280-84 (2d Cir. 1990) (implying that if defendant had presented a sufficient record, the court may have stricken later punitive damages award as unconstitutional); Racich v. Celotex Corp., 887 F.2d 393, 398 (2d Cir. 1989) ("We agree that the multiple imposition of punitive damages for the same course of conduct may raise serious constitutional concerns, in the absence of any limiting principle.”); In re Sch. Asbestos Litig., 789 F.2d 996, 1005 (3d Cir. 1986) (declaring that "powerful arguments have been made that, as a matter of constitutional law or of substantive tort law, the courts shoulder some responsibility for preventing repeated awards of punitive damages for the same acts or series of acts”); In re Fed. Skywalk Cases, 680 F.2d 1175, 1188 (8th Cir. 1982) ("Unlimited multiple punishment for the same act determined in a succession of individual lawsuits and bearing no relation to the defendants' culpability or the actual injuries suffered by victims, would violate the sense of 'fundamental fairness' that is essential to constitutional due process."). 


\section{Allocating Settlement Money to Unrelated Projects and Handpicked Organizations}

States vary in how they treat funds collected as a result of an enforcement action targeting unfair or deceptive business practices. These amounts can be substantial-in the tens or hundreds of millions of dollars-as the prior section shows.

Many state laws either do not expressly address the use of money recovered through UDAP litigation or provide AGs and other officials with wide discretion as to how they spend funds received as a result of litigation. When consumer protection funds accumulate large balances, tension can result between AGs and legislatures eying the funds as a source of money for other pressing state needs or to fill budget gaps. ${ }^{277}$ In some states, government auditors have identified a lack of proper controls in the operation and use of the recovered funds. ${ }^{278}$ In addition, some AGs have allocated money from UDAP settlements and judgments to outside organizations or causes that have little or no connection to the litigation or to addressing the type of conduct that spurred the lawsuit or any harm that occurred. Critics of this type of spending have charged that AGs inappropriately use the state's recovery to support their reelection prospects or advancement to higher office, rather than for consumer interests. ${ }^{279}$

277. See, e.g., Dan Boyd, Lawmakers Raid State Coffers for \$6.3B Spending Plan, AlBuQUERQUE J. (Feb. 4, 2016), https://www.abqjournal.com/718449/house-panel-endorses-6-3bspending-plan-on-12-5-vote.html; Jeff Jenkins, House Committee Guts Attorney General's Consumer Protection Fund, METRONEws (Mar. 3, 2014), http://wvmetronews.com/2014/03/03/ house-committee-guts-attorney-generals-consumer-protection-fund/; Rachel Leingang \& Luige del Puerto, Budget Deal Raids Consumer Protection Fund, ARIZ. CAPITOL TiMES (Mar. 6, 2015), http://azcapitoltimes.com/news/2015/03/06/budget-deal-raids-consumer-protection-fund/.

278. See, e.g., W. Va. Legis. Post Audit Div., W. Va. Legis. Post Audit Rep.: W. Va Att'y Gen.'s Office Consumer Prot. Recovery Fund, For the Period July 1, 2011 - June 30, 2012 (2013), http://www.legis.state.wv.us/legisdocs/reports/agency/PA/PA_2013_515.pdf; see also Dave Boucher, Audit of Ex-W. Va. Attorney General Finds Mismanagement of Settlement Fund, Charleston Gazette-Mail (June 25, 2013), http://www.wvgazettemail.com/News/ 201306240187.

279. For example, five-term West Virginia Attorney General Darrell McGraw was heavily criticized for spending settlement money to publicize the activities of his office-often during election years - and on trinkets such as key chains and bumper stickers bearing his name. See Richie Heath, Their View: McGraw Owes West Virginians an Explanation, W. VA. REC. (Aug. 23, 2012), http://wvrecord.com/stories/510603351-their-view-mcgraw-owes-west-virginians-anexplanation. Arkansas AG McDaniel came under fire for using proceeds from the state's Zyprexa settlement to fund an advertising campaign and website promoting his office's consumer protection activities, called “Got Your Back Arkansas.” John O’Brien, Ark. AG Using Settlement Funds for 'Got Your Back' Campaign, LEGAL NEWSLINE (Mar. 6, 2012), http://legalnewsline.com/stories/510526575-ark-ag-using-settlement-funds-for-got-your-backcampaign. 
For example, Arkansas AG Dustin McDaniel allocated \$425,000 of the state's \$21 million share of a multistate settlement targeting health claims made with respect to Dannon's Activia and DanActive products to three local hunger relief organizations. ${ }^{280}$ Some criticized this action as "trying to buy some votes," ${ }^{281}$ while others insinuated nepotism was at play. ${ }^{282}$ In a separate instance, McDaniel, a former police officer, announced that he would donate $\$ 700,000$ of settlement money his office received as a result of a multi-state UDAP action against two pharmaceutical makers to the Arkansas State Police Foundation. ${ }^{283}$ Money received as a result of the lawsuit, which alleged the manufacturers violated drug manufacturing standards, would be used to build a new training facility at a police shooting range. ${ }^{284}$

In California, half of the $\$ 16$ million settlement from Orange County's UDAP settlement with Toyota over sudden unintended acceleration claims went to fund county programs to address gang violence. $^{285}$ Of the remaining $\$ 8$ million, $\$ 4$ million was allocated to pay for the costs of the lawsuit, including the fees of outside counsel, and $\$ 4$ million was retained by Orange County District Attorney Tony Rackauckas's office to “fight economic crime." 286 The District Attorney then came under fire from the Orange County Board of Supervisors,

280. See Press Release, Ark. Att'y Gen., Settlement Funds Will Help Fight Hunger in Arkansas (Apr. 8, 2011) [hereinafter Ark. Press Release], http://ag.arkansas.gov/newsroom/index.php\%3Fdo\% 3AnewsDetail=1\%26news_id=403.

281. Sarah D. Wire, Officers' Agenda in Books: Prison Overhaul, Tax Cut Now Law, NORTHWEST ARK. DEMOCRAT GAZETTE, (May 2, 2011), http://www.nwaonline.com/news/2011/ may/02/officers-agenda-books-20110502/ (quoting Arkansas Lieutenant Governor Mark Darr).

282. Dan Greenberg, ADVANCE ARK. InsT., Why Is Dustin McDaniel Superseding the Legislature and Breaking the Law (June 10, 2011), http://www.thearkansasproject.com/wpcontent/uploads/2011/06/cypresnet.pdf (noting McDaniel's wife served at the time on the board of one of the organizations).

283. Ark. Att'y Gen. Dustin McDaniel, Remarks to the Arkansas State Police Foundation (July 1, 2011), $\quad$ http://www.arktimes.com/images/blogimages/2011/07/12/1310497541mcdanielspeech.pdf. McDaniel stated that he would rather donate the money to a good cause than "fill budget holes for legislators." Id.

284. Editorial, Show Us the Money, ARK. Times (Nov. 23, 2011), http://www.arktimes.com/arkansas/show-us-the-money/Content?oid=1951442.

285. Tony Saavedra, Toyota Settles with O.C. D.A. for \$16 Million, ORAnGE CNTY. REG. (Aug. 21, 2013), http://www.ocregister.com/articles/toyota-502946-rackauckas-acceleration.html.

286. David McAfee, Toyota Pays \$16M to Settle Calif. DA’s Acceleration Suit, LAW360 (Apr. 5, 2013), http://www.law360.com/articles/430817/toyota-pays-16m-to-settle-calif-da-s-accelerationsuit. 
whose members were frustrated that none of the settlement funds came back to the county's discretionary budget. ${ }^{287}$

Michigan AG Mike Cox announced that he would use \$500,000 of the state's settlement with Countrywide Financial Group over mortgage foreclosure practices to fund two Grand Rapids-area parks. ${ }^{288}$ The AG viewed park improvements as helping to stabilize property values in urban areas, while critics viewed the allocation of state funds as a way to gain support for a run for governor. ${ }^{289}$ He then redirected the money to United Way. ${ }^{290}$ While the bulk of the settlement, $\$ 6.6$ million of the $\$ 9.9$ million total, would be distributed to 3,700 former Countrywide customers who would receive about $\$ 1,800$ each, ${ }^{291}$ some local and state leaders felt the remaining funds could have been better spent to help families who lost their homes to foreclosure. ${ }^{292}$

Kentucky AG Jack Conway distributed \$32 million of a UDAP settlement with two pharmaceutical manufacturers to an array of drug treatment programs. ${ }^{293}$ The lawsuits, however, did not address substance

287. Erika Aguilar, DA's Office Comes up Short in Orange County Budget, 89.3 KPCC (May 13, 2015), http://www.scpr.org/news/2015/05/13/51656/orange-county-budget-battle-to-watch-isover-d-a-s/.

288. See Emily Zoladz, Countrywide Money for Parks Draws Criticism; Secchia Defends Millennium Donation Because of its Urban Location, GRAND RAPIDS PRESS (Mar. 18, 2009), http://blog.mlive.com/grpress/news_impact/print.html?entry=/2009/03/countrywide_money_for_par ks_dr.html.

289. See Jim Harger, Michigan Attorney General Mike Cox Says He’s “Dumbfounded” that Grand Rapids, Kent County Leaders Are Questioning \$500,000 in Local Park Donations, GRAND RAPIDS PRESS (Mar. 20, 2009), http://www.mlive.com/news/grandrapids/index.ssf/2009/03/michigan_attorney_general_mike.html (reporting that critics charged that Cox, who was considering a run for Governor, distributed the money to further his political ambitions); Jim Harger, State, Local Legislators Call for Reevaluation of Countrywide Mortgage Settlement Funds After Surprise Parks Money, GRAND RAPIDS PRESS (Mar. 19, 2009), http://www.mlive.com/news/grand-rapids/index.ssf/2009/03/state_local_legislators_call_f.html (reporting Democrats charged, however, that Cox decided to give the money to the parks after being approached by a major GOP donor who also heads fundraising for one of the county-owned parks).

290. Beth Loechler, Attorney General Mike Cox Changes Plan for Foreclosure Settlement Money, Shifts $\$ 500,000$ from Parks to United Way, GRAND RAPIDS PRESS (Mar. 22, 2009), http://www.mlive.com/news/grand-rapids/index.ssf/2009/03/attorney_general_mike_cox_chan.html.

291. See Press Release, Mich. Office of the Att’y Gen., Countrywide Financial to Pay $\$ 6.6$ Million to 3,674 Michigan Borrowers (undated), http://www.michigan.gov/ag/0,1607,7-164-46849218726—,00.html (last visited Oct. 7, 2016).

292. Zoladz, supra note 288.

293. AG Jack Conway announced that the settlement would be divided as follows: $\$ 19$ million to start a grant program to finance juvenile abuse treatment programs; $\$ 6$ million to administer the state’s electronic prescription drug monitoring program; \$2.52 million for scholarships to seek treatment at the state's Recovery Kentucky Centers; $\$ 1.5$ million to the University of Kentucky to assist treatment providers; \$1 million to support drug programs for pregnant women; \$1 million for a school-based substance abuse screening tool with the state Department of Education; $\$ 560,000$ to help create 14 drug-free homes for people making the transition out of residential drug treatment programs; $\$ 500,000$ to complete construction of a treatment center in Ashland, Kentucky; and 
abuse. They alleged that manufacturers violated the Kentucky Consumer Protection Act by failing to disclose cardiovascular risks associated with Vioxx and Avandia. ${ }^{294}$ One legislative leader did not object to how the money was going to be used, but questioned the legality of the arrangement since he believed Kentucky law requires depositing settlement money in the General Fund and appropriation by the legislature. ${ }^{295}$

Some state AGs have claimed that the power to decide how settlement money is spent is within his or her sole discretion, to the ire of lawmakers. For example, in February 2015, the U.S. Department of Justice announced a $\$ 1.375$ billion settlement on behalf of the federal government, nineteen states, and the District of Columbia with Standard \& Poors Financial Services LLC, along with its parent corporation McGraw Hill Financial, Inc., to resolve allegations involving how it issued ratings for residential mortgage-backed securities and collateralized debt obligations. ${ }^{296}$ Maine's claims, brought under its UDAP law, gained the state a \$21.5 million share of the settlement, which AG Janet Mills described "as the largest ever one-time court settlement in the [state's] history." 297 Maine Governor Paul LePage challenged the AG's authority to unilaterally allocate state funds, noting that the power to appropriate revenue is constitutionally given to the legislature checked by the Executive. ${ }^{298}$

These practices are not only politically controversial, but can lead to legal and fiscal problems for the state. The principal example is West Virginia AG McGraw's use of funds collected as a result of settlements

$\$ 250,000$ to create a database to evaluate the outcomes of juvenile treatment. Press Release, Ky. Office of the Att'y Gen., Attorney General Conway Announces \$32 Million for Drug Addiction Treatment (Jan. 6, 2014), http://migration.kentucky.gov/newsroom/ag/drugaddictiontreatment.htm.

294. Id.

295. Ronnie Ellis, Drug Settlement Funds to Benefit Recovery Centers, Glasgow Daily TIMES (Jan. 6, 2014), http://www.glasgowdailytimes.com/news/local_news/drug-settlement-fundsto-benefit-recovery-centers/article_fc9ddc77-52c0-5c01-b295-535232dcc95e.html (referring to Senate President Robert Stivers); see Ky. ReV. StAT. AnN. § 48.005 (West 2006 \& Supp. 2013).

296. Press Release, Dep’t of Justice, Justice Department and State Partners Secure \$1.375 Billion Settlement with S\&P for Defrauding Investors in the Lead Up to the Financial Crisis (Feb. 3, 2015), https://www.justice.gov/opa/pr/justice-department-and-state-partners-secure-1375-billionsettlement-sp-defrauding-investors.

297. Dennis Hoey, LePage Plans Bill to Bar Attorney General from Allocating Settlement, PoRTLAND PRESS HERALD (Feb. 27, 2015), http://www.pressherald.com/2015/02/26/lepage-plansbill-to-bar-attorney-general-from-allocating-settlement/.

298. Id. 
with two pharmaceutical manufacturers, Dey Inc. and Purdue Pharma. ${ }^{299}$ In both of the underlying lawsuits, AG McGraw claimed that the manufacturers' marketing practice resulted in losses for the state's Medicaid program. ${ }^{300}$ AG McGraw allocated most of the \$850,000 Dey settlement money to the Public Employees Insurance Agency, retaining $\$ 100,000$ for his office's consumer protection fund. ${ }^{301}$ He distributed the $\$ 10$ million Purdue settlement, which resolved allegations that the company misrepresented the potential for addiction to OxyContin, more broadly: " $\$ 500,000$ to the University of Charleston for a pharmacy school[,]" ${ }^{302} \$ 180,000$ for a nursing program run by the wife of the State Senate president, ${ }^{303}$ and an unknown amount to help pay for a 12,000 foot fitness training center for a West Virginia State Police Academy center, ${ }^{304}$ in addition to funding substance abuse and other programs. ${ }^{305}$ The outside counsel hired to litigate the West Virginia case earned more than $\$ 3$ million. ${ }^{306}$ The state agencies in whose name McGraw sued received virtually none of the settlement, and the federal government,

299. See Jessica M. Karmasek, Critics Say W. Va. AG Should Be Accountable for Medicaid Gap, LEGAL NEWSLiNE (Nov. 3, 2011), http://legalnewsline.com/stories/510525777-critics-say-wva-ag-should-be-accountable-for-medicaid-gap.

300. John O’Brien, Feds Want a Stay in McGraw Settlement Funds Issue, Legal NewsLine (July 26, 2010), http://legalnewsline.com/stories/510523254-feds-want-a-stay-in-mcgrawsettlement-funds-issue; John O’Brien, Judge Rules Against McGraw, W. Va. Budget to Be Shorted, LEGAL NEWSLiNE (Apr. 7, 2010), http://legalnewsline.com/stories/510522701-judge-rules-againstmcgraw-w-va-budget-to-be-shorted.

301. W. Va. Dep’t of Health \& Human Res. v. Sebelius, 709 F. Supp.2d 487, 491 (S.D. W. Va. 2010), aff'd, 649 F.3d 217 (4th Cir. 2011). The private attorneys hired by McGraw received $\$ 250,000$ in attorneys' fees. See Editorial, McGraw Exposed the State to Losses, CHARLESTON GAZETTE-MAIL (Aug. 10, 2012), http://www.wvgazettemail.com/Opinion/Editorials/201208090179 \#sthash.s8fVSURr.dpuf; John O’Brien, Feds to W. Va.: Pay up Money from McGraw Settlement, W. VA. REC. (Aug. 17, 2007), http://wvrecord.com/stories/510592610-feds-to-w-va-pay-up-moneyfrom-mcgraw-settlement.

302. See John O’Brien, W. Va. AG Might Be Done Appealing \$3.1M Disputes with Feds, LEgAL NewsLine (Oct. 6, 2011) [hereinafter O’Brien, $W$. Va. AG], http://legalnewsline.com/stories/510525600-w-va-ag-might-be-done-appealing-3-1m-disputes-withfeds.

303. See Steve Korris, AG's \$180,000 Award to Tomblin's Wife's College Raises Eyebrows, W. VA. REC. (Apr. 13, 2006), http://wvrecord.com/stories/510590159-ag-s-180-000-award-to-tomblins-wife-s-college-raises-eyebrows.

304. See Ashley B. Craig, Police Academy Gets New Training Center, CHARLESTON GAZETTEMAIL (Apr. 25, 2012), http://www.wvgazettemail.com/News/201204240241.

305. See John O’Brien, More OxyContin Money Dished Out by AG McGraw, LEGAL NEwSLine (Aug. 6, 2007), http://legalnewsline.com/stories/510518420-more-oxycontin-moneydished-out-by-ag-mcgraw.

306. See In re W. Va. Dept. of Health and Human Res., DAB No. 2278, at 12 (Departmental Appeals Bd., U.S. Dep’t of Health and Human Servs. Oct. 29, 2009) [hereinafter DAB No. 2278], http://www.hhs.gov/dab/decisions/dabdecisions/dab2278_.pdf. 
which funds a substantial portion of the state's Medicaid program, received nothing from both of these settlements. ${ }^{307}$

The U.S. Department of Health and Human Services (HHS) withheld from West Virginia's Department of Health and Human Resources $\$ 446,607$ for the Dey settlement ${ }^{308}$ and \$2,732,968 for the Purdue settlement. $^{309}$ HHS claimed it was owed these amounts since West Virginia did not reimburse HHS for its share in the Medicaid overpayments or inform HHS about these settlements. ${ }^{310}$ McGraw filed suit against HHS, but the U.S. Court of Appeals for the Fourth Circuit held that a "[s]traightforward application of the Medicaid Act" shows that HHS had the right to withhold the settlement amount in Medicaid funds from the state. ${ }^{311}$

Following this controversy, McGraw lost his reelection bid to West Virginia AG Patrick Morrisey, who during the campaign promised to reform the office. As promised, the new AG instituted a number of reforms, including a competitive bidding process and caps on contingency fees for outside attorneys. ${ }^{312}$ He also worked with the governor and legislature to turn over a portion of settlement funds above that needed for the operation of his office's consumer protection division to the state's General Fund. ${ }^{313}$ For example, in 2013, the West Virginia legislature, with the support of AG Morrisey, reallocated \$7.5 million of

307. See Heath, supra note 279; O’Brien, W. Va. AG, supra note 302; John O’Brien, McGraw Takes Medicaid Withhold to Federal Court, LEgAL NEwsLine (Jan. 21, 2010), http://legalnewsline.com/stories/510522250-mcgraw-takes-medicaid-withhold-to-federal-court; John O’Brien, McGraw Settlement Causes \$446K Hole in Medicaid Funding, LEGAL NEwsLine (June 29, 2009), http://legalnewsline.com/stories/510521120-mcgraw-settlement-causes-446k-hole-inmedicaid-funding.

308. See In re W. Va. Dep't of Health and Human Res., DAB No. 2250, at 14-15 (Departmental Appeals Bd., U.S. Dep't of Health and Human Servs. May 26, 2009), http://www.hhs.gov/dab/decisions/DAB2250.pdf.

309. See DAB No. 2278, supra note 306, at 17.

310. See id.

311. W. Va. Dep't of Health \& Human Res. v. Sebelius, 649 F.3d 217, 224-25 (4th Cir. 2011).

312. See Press Release, W. Va. Office of the Att'y Gen., AG Patrick Morrisey Announces New Policy on Hiring Outside Council (Mar. 21, 2013), https://web.archive.org/web/20150922215125/ http:/www.ago.wv.gov/pressroom/2013/Pages/AG-Patrick-Morrisey-Announces-New-Policy-onHiring-Outside-Counsel.aspx; Office of the W. Va. Att'y Gen., Outside Counsel Policy, Policy No. WVAGO-004 (July 16, 2013), http://www.ago.wv.gov/Documents/Outside\%20Counsel\% 20Policy\%20\%28Final\%20-\%20July\%2016\%2c\%202013\%29.pdf.

313. See Press Release, W. Va. Office of the Att'y Gen., Attorney General Morrisey Works With Governor, Legislature to Reform Process for Appropriating Settlement Money (Apr. 18, 2013), https://web.archive.org/web/20150922233011/http://www.ago.wv.gov/pressroom/2013/Pages/Attorn ey-General-Morrisey-Works-With-Governor,-Legislature-to-Reform-Process-for-AppropriatingSettlement-Money.aspx; see also Short Takes: W. Va. Att'y Gen. Patrick Morrisey Settles Suit the Right Way, ChARLESTON GAZETTE-MAIL (June 14, 2014), http://www.wvgazettemail.com/ article/20140614/DM04/140619664. 
the unappropriated surplus balance in the Consumer Protection Recovery Fund to the State Fund, General Revenue. ${ }^{314}$

\section{LEFT UNCHECKED, THESE PRACTICES WILL EXPAND}

While many examples of AG enforcement of UDAP laws explored in this Article involve the pharmaceutical industry, a broad range of businesses are bracing themselves for similar actions.

The types of practices discussed in this Article apply to any industry. Pharmaceutical manufacturers have become prime targets because they are viewed as deep pockets by private lawyers who have partnered with state AGs. Given the success of this model in leading to lucrative settlements, these types of enforcement practices are likely to expand to new industries and types of conduct. As noted earlier, some of these practices have already arisen in cases involving nursing homes, mortgage lenders, and automobile manufacturers, among others.

For example, two areas where expanded AG use of UDAP enforcement actions appears particularly likely with significant potential for misuse of these laws are data breaches and food marketing practices.

After a data breach, companies are often accused of having failed to adequately protect their customers' information. Historically, the FTC has taken the lead in privacy law enforcement. Now, with increased storage of consumer data and a rise in security breaches, state AGs and class action lawyers are increasingly bringing actions under state UDAP laws and other legal theories. Many states have adopted statutes that specifically empower AGs to use their UDAP authority to enforce data security breach notification requirements. ${ }^{315}$ AGs have used these laws to impose penalties on companies when a data breach occurs, whether it results from an individual employee's carelessness or a malicious hacker. For instance, Health Net settled claims with then-Connecticut AG

314. 2013 W. Va. Legis. Serv. Ch. 1, 1st Extraordinary Sess. (S.B. 1005).

315. See, e.g., ARIZ. Rev. Stat. ANN. § 18-545 (West, Westlaw current though 2d Reg. Sess. of 52nd Legis.); Conn. Gen. Stat. Ann. § 36a-701b(g) (West 2011 \& Supp. 2014); Del. Code ANN. tit. 6, § 12B-104 (West 2006 \& Supp. 2016); FLA. STAT. ANN. § 501.171(9) (West, Westlaw through 2016 Reg. Sess.); 815 ILl. Comp. StAT. AnN. 530/20 (West 2008); IOWA CodE ANN. § 715C.2(8) (West 2013 \& Supp. 2014); MD. CODE ANN., CoM. LAW § 14-3508 (West 2013); MASS. Gen. LAWS ANN. ch. 93H, § 6 (West Supp. 2014); Miss. CodE ANN. § 75-24-29(8) (West Supp. 2013); Mont. Code AnN. § 30-14-1705(3) (2013); N.H. ReV. StAT. ANN. § 359-C:21(II) (2009); N.C. Gen. StAT. ANN. § 75-65(i) (West 2012); N.D. CENT. Code AnN. § 51-30-07 (West 2008); OR. Rev. Stat. AnN. § 646A.604(9)(a) (West 2011); 73 PA. StAT. AND Cons. Stat. AnN. § 2308 (West 2008); TenN. CodE ANN. §§ 47-18-2105(d), 47-18-2106 (West 2002 \& Supp. 2014); VT. StAT. ANN. tit. 9, § 2435(g) (West 2007 \& Supp. 2013); W. VA. CODE ANN. § 46A-2A-104 (West Supp. 2013). 
Richard Blumenthal in $2010^{316}$ and Vermont AG William Sorrell in $2011^{317}$ after the insurer lost a hard drive that included protected health information. There was no indication that anyone had actually accessed the information.

Massachusetts AG Martha Coakley entered a similar settlement in 2011 with a company that owns several popular bars and restaurants in the Boston area. In that instance, malcode installed on The Briar Group's computer systems allowed hackers access to customers' credit card and debit card information. ${ }^{318}$ The complaint alleged the business violated the state's UDAP law by failing to adequately protect their customers' personal information. ${ }^{319}$ Under the terms of the settlement, the company must adopt additional security measures and investigate any potential misuse of the stolen data and alert customers if there is evidence of fraudulent transactions. ${ }^{320}$ The company also agreed to pay the state $\$ 110,000$ in civil penalties. ${ }^{321}$

Thus far, AG actions have been measured responses to data breaches compared to consumer class actions, which have sought substantial damages even in absence of evidence of misuse. Private class actions have faced significant legal challenges, such as the need to show an actual injury. ${ }^{322}$ Should an AG empower a private lawyer to seek civil

316. Press Release, Conn. Office of the Att'y Gen., Attorney General Announces Health Net Settlement Involving Massive Security Breach Compromising Private Medical and Financial Info (July 6, 2010), http://www.ct.gov/ag/cwp/view.asp?A=2341\&Q=462754. In addition to spending millions of dollars to provide private identity theft protection to individuals whose information was included on the hard drive, Health Net paid Connecticut $\$ 250,000$. See id. The settlement also provided for Health Net to pay an additional $\$ 500,000$ if evidence established that the lost drive was accessed and personal information used illegally. See id. The Connecticut settlement was hailed by Blumenthal as the "first of its kind in the nation." Id.

317. Consent Decree, Final Order and Judgment, Vermont v. Health Net, Inc., No. 2:11-cv0016 (D. Vt. Jan. 20, 2011), http://ago.vermont.gov/assets/files/Health\%20Net\%20Proposed\%

20Settlement.pdf (agreeing to pay state \$55,000); see also Press Release, Vt. Office of the Att’y Gen., Attorney General Settles Security Breach Allegations Against Health Insurer (Jan. 18, 2011), http://ago.vermont.gov/focus/news/attorney-general-settles-security-breach-allegations-againsthealth-insurer.php.

318. Final Judgment by Consent, Commonwealth v. Briar Group, LLC, Civ. No. 11-1185B, (Mass. Super. Ct. Mar. 28, 2011), http://privacylaw.proskauer.com/uploads/file/Briar\%20Group\% 20Judgment\%203_28_11.pdf; see also Press Release, Mass. Office of the Att'y Gen., Major Boston Restaurant Group that Failed to Secure Personal Data to Pay \$110,000 Under Settlement with AG Coakley (Mar. 28, 2011), http://www.mass.gov/ago/news-and-updates/press-releases/2011/ restaurant-group-pay-110000-under-ag-settlement.html.

319. Final Judgement by Consent, supra note 318, at 2.

320. Id. at 3-5.

321. Id. at 5 .

322. See generally Liisa M. Thomas, Robert H. Newman, \& Alessandra Swanson, Inst. for Legal Reform, U.S. Chamber, A Perilous Patchwork: Data Privacy and Civil Liability in the Era of 
penalties on behalf of the state after a data breach, the aggregation of penalties based on each person whose data was potentially exposed, even if there is no evidence that it was actually misused, could result in extraordinary liability.

Another potential target for UDAP enforcement actions is the food industry. Private lawyers have circulated a pitch to state AGs suggesting that the state hire them to bring lawsuits against food manufacturers and restaurant chains to hold them financially responsible for medical costs associated with obesity-related conditions. ${ }^{323}$ The letter suggested that AGs delegate the state's subpoena power under UDAP laws to private lawyers. They would use the state's power to attempt to find internal documents that could tarnish the public's perception of food makers ${ }^{324}$ and place targeted "Big Food defendants" at a distinct disadvantage even before filing suit. ${ }^{325}$ An investigation by Politico revealed that the law firm behind the proposal had circulated it to AGs in at least sixteen states. ${ }^{326}$

To date, no AG has taken the bait on that proposal, possibly as a result of public disclosure of the lawyers' marketing effort. In recent years, however, plaintiffs' attorneys, relying on UDAP laws, have filed a surge of consumer class actions challenging food marketing practices. ${ }^{327}$ The most popular style of these claims alleges that a product is misleadingly advertised as "natural" due to its processing or the presence of genetically-modified or other ingredients. ${ }^{328}$

$\begin{array}{lcc}\text { Data } & \text { Breach } & 17-27 \\ \text { http://www.instituteforlegalreform.com/uploads/sites/1/APerilousPatchwork_Web.pdf. }\end{array}$

(2015),

323. Letter from Paul L. McDonald, Partner, Valorem Law Group, to the Hon. Kathleen Kane, Penn. Att'y Gen., Redacted Litigation Proposal: Using Parens Patriae Authority to Prosecute [Redacted] Claims Against "Big Food" for its Contribution to the States' \$30 Billion Annual Medicaid Bill for Obesity (Feb. 9, 2013) (on file with author).

324. Id. at 3 (" $[P]$ re-complaint, one-way discovery obtained via subpoenas under state consumer protection statutes could alter perceptions [that food is not defective or as addictive as cigarettes are].”).

325. Id. at 4 ("[P]re-compliant, one-way discovery obtained via subpoenas under state consumer protection statutes offers states unique litigation advantages, e.g., the ability to thoroughly vet claims, with the assistance of experts, before filing any complaint, while posing real risks to potential Big Food defendants.”).

326. Helena Bottemiller Evich, The Plot to Make Big Food Pay, Politico (Feb. 12, 2014), http://www.politico.com/story/2014/02/food-industry-obesity-health-care-costs-103390.

327. See CARy Silverman, Food Class Action Litigation, in InSt. FOR Legal Reform, U.S. Chamber, The New Lawsuit Ecosystem: Trends, Targets and Players 88-95 (2013), http://www.instituteforlegalreform.com/uploads/sites/1/The_New_Lawsuit_Ecosystem_pages_web. pdf (reporting 150 food class actions filed between 2011 and 2013, up from about 18 in 2008).

328. See Mike Esterl, Some Food Companies Ditch 'Natural' Label, Wall ST. J. (Nov. 6, 2013), http://www.wsj.com/articles/SB10001424052702304470504579163933732367084. 
As their pitch to AGs to bring obesity-related litigation shows, plaintiffs' lawyers certainly are aware that bringing UDAP actions through state AGs, rather than as private class actions, can avoid challenges they face in such suits, such as showing consumers were actually injured by allegedly deceptive marketing and what, if any, loss consumers incurred. Instead, a state AG enforcement action would allow for significant civil penalties for each product sold.

AGs have already brought UDAP actions against food makers. As discussed earlier, thirty-nine AGs joined the FTC in a settlement with Dannon of claims alleging that the company exaggerated the health benefits of its Activia yogurt and its DanActive dairy drink. ${ }^{329}$ Time will tell whether AGs are willing to move from cases against food companies involving claimed nutritional benefits or health risks to partnering with private lawyers to bring the types of claims that are more common in class action litigation.

\section{RECOMMENDATIONS}

Courts and legislatures can address the issues raised in this Article while fully preserving the ability of state AGs to stop deceptive practices, obtain restitution for any consumer who suffered a loss, and impose civil penalties on those who willfully violate the law. They can do so by providing transparency in state hiring of outside counsel, fostering consistency between UDAP litigation and a business's compliance with government regulations, and curtailing the potential for excessive civil penalties. They can also ensure that UDAP actions are not viewed as a means to create a slush fund for AGs, particularly given ever tightening state budgets.

\section{A. Provide Transparency in the State's Hiring and Payment of Outside Counsel and Require Government Control over Litigation}

In order to address concern with state retention of private attorneys on a contingency-fee basis, fifteen state legislatures have adopted safeguards that apply when an AG or other state official retains outside

329. See Press Release, FTC, Dannon Agrees to Drop Exaggerated Health Claims for Activia Yogurt and DanActive Dairy Drink (Dec. 15, 2010), https://www.ftc.gov/news-events/pressreleases/2010/12/dannon-agrees-drop-exaggerated-health-claims-activia-yogurt; see also Ark. Press Release, supra note 280 (discussing distribution of Arkansas portion of settlement to hunger relief groups). 
counsel to represent the state since $2010 .^{330}$ While the specific provisions of these laws vary from state to state, common provisions include (1) requiring government officials who have authority to hire outside counsel to make a written finding that hiring outside counsel is cost-effective and in the public interest before hiring private lawyers; (2) subjecting the hiring process to competitive public bidding; (3) posting contingency-fee contracts and payments made to private lawyers on a public website; (4) requiring outside counsel to maintain detailed time and expense records; (5) mandating that government lawyers maintain control over the litigation; (6) placing with the state exclusive authority to settle a case; (7) adopting a sliding scale for contingency-fees based on the amount recovered, along with a maximum fee cap; and (8) precluding lawyers from collecting fees based on a percentage of the civil penalties imposed.

Some states, such as Louisiana, Nevada, and New Hampshire, go further to protect the legislature's appropriation authority by requiring the AG to obtain legislative approval before retaining an attorney on a contingency-fee basis. ${ }^{331}$ For instance, Louisiana enacted a law in 2014 that codified a Louisiana Supreme Court decision finding that the state AG or a state agency may not hire outside counsel on a contingency-fee basis unless specifically authorized by the legislature. ${ }^{332}$ The law also prohibits outside counsel from demanding that defendants or any other third party pay them for representing the state. ${ }^{333}$ While requiring the AG to obtain approval from the legislature prior to hiring on a

330. See Ala. Code § 41-16-72 (2013); ARIZ. Rev. Stat. ANN. § 41-4801 et seq. (Supp. 2015); 2015 Ark. Act 851 (S.B. 204) (2015) (to be codified at ARK. CodE ANN. § 25-16-714); FLA. STAT. ANN. § 16.0155 (West 2014); 2011 Ind. Legis. Serv. P.L. 101-2011 (S.E.A. 214) (2011) (to be codified at IND. CODE § 4-6-3-2.5); IOWA CodE ANN. § 23B.1 et seq. (West Supp. 2014); 2014 La. Sess. Law Serv. 796 (2014) (H.B. 799) (amending LA. STAT. ANN. §§ 42:262, 49:259); MIss. CoDE ANN. §§ 7-5-5, 7-5-8, 7-5-21, 7-5-39 (Supp. 2013); 2011 Mo. Legis. Serv. S.B. 59 (2011) (amending Mo. REV. STAT. §§ 34.376 et seq.); 2015 Nev. Laws Ch. 85 (S.B. 244) (2015) (to be codified in NeV. Rev. StAT. § 228.110(2)); 2014 N.C. Laws S.L. 2014-110 (S.B. 648) (2014) (amending N.C. GEN. STAT. § 114-9.2 et seq.); 2015 Ohio Laws 6 (S.B. 38) (to be codified at OHIO REv. CodE ANN. $\S 9.49$ et seq.); 2015 Utah Laws Ch. 362 (S.B. 233) (2015) (to be codified at UTAH CODE ANN.§ 675-33); 2016 W. Va. Legis. Serv. Ch. 27 (H.B. 4007) (amending W. VA. CoDE §§ 5-3-3, 5-3-4); 2013 Wisc. Legis. Serv. Act 105 (A.B. 27) (amending WIS. STAT. §§ 14.11, 20.9305).

331. See 2014 La. Sess. Law Serv. 796 (H.B. 799) (amending LA. StAT. ANN. §§ 42:262, 49:259); 2015 Nev. Laws Ch. 85 (S.B. 244) (to be codified in NEV. REV. STAT. § 228.110(2)); Order Granting Defendants' Motion for Protective Order, State v. Actavis Pharma, Inc., No. 217-2015-CV00566 (N.H. Super. Ct. Mar. 8, 2016) (interpreting N.H. Rev. STAT. ANN. § 7:12 (2013), https://cei.org/sites/default/files/NH\%20court\%20ruling\%20on\%20contingency\%20fee\%20contract s.pdf.

332. 2014 La. Sess. Law Serv. 796 (H.B. 799) (amending LA. STAT. ANN. §§ 42:262, 49:259); see also Meredith v. Ieyoub, 700 So. 2d 478, 484 (La. 1997).

333. 2014 La. Sess. Law Serv. 796 (H.B. 799) (amending LA. STAT. AnN. §§ 42:262, 49:259). 
contingency-fee basis might not be politically feasible in some states, state legislatures should at a minimum establish transparency requirements along with a competitive bidding process.

In addition, courts have a significant role in ensuring that UDAP actions brought by states through outside counsel are litigated to advance the public, not private, interest. Courts should carefully evaluate whether existing state law authorizes an AG to retain outside counsel on a contingency-fee basis. When such arrangements are proper, courts should require government control over the litigation "with teeth." Courts should not take boilerplate statements in the retention agreement placing control with the government at face value, but evaluate the state's involvement in shaping the investigation, complaint, litigation strategy, any trial, and settlement. If the government has, in practice, ceded its enforcement authority to private lawyers, then the court should not hesitate to find a due process violation, especially when the action seeks civil penalties.

\section{B. Foster Consistency Between UDAP Actions and Government Regulation}

States can also interpret their UDAP laws consistently with regulatory policy, and recognize that businesses that comply with regulatory obligations should not be subject to unpredictable and inconsistent liability. In states lacking a provision recognizing the interaction between UDAP enforcement and activities already regulated by government agencies, state legislatures should consider adopting a law similar to most other states. Such a law might clarify that the UDAP statute does not apply to "acts or practices permitted under laws of this State or the United States or under rules, regulations, or decisions interpreting such laws.”

In states with such provisions, but where courts have interpreted them in a manner inconsistent with their purpose, state legislatures can amend the law as needed to preclude UDAP liability when the conduct at issue was permitted by government regulators or the product's labeling or marketing was specifically approved by an agency charged with safeguarding the public.

For their part, courts can find that conduct that complied with government regulations or was approved by a government agency is not unfair or deceptive as a matter of law, even if the state does not have a 
codified regulatory compliance provision. ${ }^{334}$ They can recognize that conduct that is already comprehensively regulated by federal or state law to protect the public does not fall under the scope of a more general UDAP law. ${ }^{335}$ Courts can also find that warning letters and other informal correspondence issued by staff at regulatory agencies without any hearing or right to appeal are more prejudicial than probative in UDAP litigation, ${ }^{336}$ and do not fall within a recognized exception to the hearsay rule. ${ }^{337}$

\section{Establish Predictability and Proportionality in Civil Penalties}

As discussed earlier, in order to establish a UDAP violation, some states only require that the alleged misrepresentation had the tendency to deceive or was capable of misleading someone regardless as to whether the defendant intended to mislead. Such a low standard of proof may be appropriate in cases where an AG is pursuing an injunction to prevent future harm, but it is improper when an AG is seeking to punish a company with civil penalties. Fault has been a predicate throughout the history of liability law, and an AG should be required to establish some degree of culpability before a court imposes civil penalties. Where needed, state legislatures should amend UDAP laws to limit civil penalties to instances in which a court finds that a business willfully engaged in an unfair or deceptive practice.

In addition, when a court is assessing penalties, an AG should be required to produce evidence of actual consumer harm. Actual harm is generally an indispensable part of all civil actions seeking damages or penalties, but the element of consumer harm is missing from some AG UDAP actions. Where an AG is only able to establish that the unfair or deceptive conduct is reasonably likely to harm consumers, but has not caused actual harm, the action should be subject to an injunction to stop the practice and a lower, if any, civil penalty. For example, a state that ordinarily provides for a civil penalty of $\$ 10,000$ per violation might provide that a prohibited practice that did not result in significant harm to

334. For example, several courts have found insurance practices fall outside the scope of a UDAP statute that does not include a regulatory compliance exemption or specifically exclude such practices. See, e.g., In re Prudential Ins. Co. of Am. Sales Practices Litig., 975 F. Supp. 584, 619 (D. N.J. 1996); Wilder v. Aetna Life \& Cas. Ins. Co., 433 A.2d 309, 310 (Vt. 1981).

335. See, e.g., White v. Wyeth, 705 S.E.2d 828, 838 (W. Va. 2010); see also Schwartz, Silverman \& Appel, supra note 95 at 105-07 (citing cases in Georgia, Maine, and Rhode Island interpreting their UDAP laws in this manner).

336. See State ex rel. McGraw v. Johnson \& Johnson, 704 S.E.2d 677, 689-91 (W. Va. 2010).

337. See Ortho-McNeil-Janssen Pharm., Inc. v. State, 432 S.W.3d 563, 579-80 (Ark. 2014). 
the public is subject to an injunction and a civil penalty not to exceed $\$ 1,000$ per violation, but no more than $\$ 1$ million for any related series of violations.

In order to alleviate some of the arbitrariness of how civil penalties can be calculated, UDAP laws should provide courts with factors to guide them in determining a fair and reasonable civil penalty. Although statutory factors are common in laws authorizing civil penalties, ${ }^{338}$ few UDAP laws include them. ${ }^{339}$ Where a statute or regulation does not provide such guidance, courts can develop and consider penalty factors. ${ }^{340}$ For example, a state law might provide that when determining

338. For example, the National Highway Traffic Safety Administration (NHTSA) considers:

(1) the nature of the defect or noncompliance; (2) knowledge by the person charged of its obligations under this chapter; (3) the severity of the risk of injury; (4) the occurrence or absence of injury; (5) the number of motor vehicles or items of motor vehicle equipment distributed with the defect or noncompliance; (6) actions taken by the person charged to identify, investigate, or mitigate the condition; (7) the appropriateness of such penalty in relation to the size of the business of the person charged, including the potential for undue adverse economic impacts; (8) whether the person has been assessed civil penalties under this section during the most recent 5 years; and (9) other appropriate factors.

See 49 U.S.C. § 30165(c). The Consumer Product Safety Administration (CPSC) considers:

(A) The nature of the product defect; (B) The severity of the risk of injury; (C) The occurrence or absence of injury; (D) The number of defective products distributed; (E) The appropriateness of such penalty in relation to the size of the business of the person charged, including how to mitigate undue adverse economic impacts on small businesses; and (F) Such other factors as appropriate.

See 16 C.F.R. § 1119.4 (2016).

339. An example of a state UDAP law that includes penalty factors is the North Carolina Unfair and Deceptive Trade Practices Act. It provides that

[i]n determining the amount of the civil penalty, the court shall consider all relevant circumstances, including, but not limited to, the extent of the harm caused by the conduct constituting a violation, the nature and persistence of such conduct, the length of time over which the conduct occurred, the assets, liabilities, and net worth of the person, whether corporate or individual, and any corrective action taken by the defendant.

N.C. GEN. Stat. ANN. § 75-15.2 (West 2012). California’s Unfair Competition Law similarly provides that a court may consider: "the nature and seriousness of the misconduct, the number of violations, the persistence of the misconduct, the length of time over which the misconduct occurred, the willfulness of the defendant's misconduct, and the defendant's assets, liabilities, and net worth." CAL. Bus. \& PROF. CODE § 17206(b) (West 2008 \& Supp. 2014). In Texas, the jury (not the court) decides whether to award a civil penalty and the amount. TEX. Bus. \& COM. CODE ANN. § 17.47(c) (West 2011). In awarding a civil penalty, Texas's deceptive trade practices law instructs the trier of fact to consider:

(1) the seriousness of the violation, including the nature, circumstances, extent, and gravity of any prohibited act or practice; (2) the history of previous violations; (3) the amount necessary to deter future violations; (4) the economic effect on the person against whom the penalty is to be assessed; (5) knowledge of the illegality of the act or practice; and (6) any other matter that justice may require.

Id. § $17.47(\mathrm{~g})$.

340. State ex rel. Wilson v. Ortho-McNeil-Janssen Pharm., Inc., 777 S.E.2d 176, 203 n.31 (S.C. 2015); see also United States v. Reader’s Digest Ass’n, Inc., 662 F.2d 955, 967 (3d Cir. 1981) (in determining civil penalty under FTC Act, considering "(1) the good or bad faith of the defendants; 
the size of an appropriate civil penalty, a court would consider such factors as: (1) the degree of culpability and good or bad faith; (2) the actual impact or injury to the public resulting from the conduct; (3) the sophistication or level of knowledge of the parties; (4) the duration of the unlawful conduct; (5) any corrective action taken; (6) whether the person actively concealed the unlawful conduct; (7) whether the person engaged in prior similar conduct; (8) the deterrent value of the penalty; (9) any other liability imposed as a result of the same course of conduct; and (10) the potential for undue adverse economic impacts. Adopting such factors is not a guarantee that courts will apply them appropriately and consistently, but would be a step forward. ${ }^{341}$

Finally, due to the potential multiplying effect on a single action due to the vagueness of "per violation," UDAP laws should place an aggregate limit on civil penalties, such as \$5 million for "any related series of violations." Federal laws providing for civil penalties include such maximum levels. ${ }^{342}$ Alternatively, UDAP laws could provide a cap linked to the actual harm to consumers or profit received by the business as a result of the violation. For example, a state law might provide that for any related series of violations, a civil penalty shall not exceed the greater of: (1) three times the actual loss caused by the violation; (2) three times the profit gained as a result of the violation; or (3) \$5 million. ${ }^{343}$

(2) the injury to the public; (3) the defendant's ability to pay; (4) the desire to eliminate the benefits derived by a violation; and (5) the necessity of vindicating the authority of the FTC”); Commonwealth v. Fall River Motor Sales, Inc., 565 N.E.2d 1205, 1211 (Mass. 1991) (applying same FTC factors to affirm $\$ 20,000$ civil penalty under Massachusetts consumer protection law); State ex rel. Humphrey v. Alpine Air Prods., Inc., 490 N.W.2d 888, 897 (Minn. Ct. App. 1992) (applying first four factors to affirm $\$ 70,000$ civil penalty under Minnesota consumer protection statutes).

341. See, e.g., Joseph P. Mohorovic, Comm'r, Consumer Prod. Safety Comm'n, Statement Regarding the Commission's Provisional Civil Penalty Settlement with Sunbeam Products, Inc. D/B/A Jarden Consumer Solutions (June 6, 2016), http://www.cpsc.gov/en/AboutCPSC/Commissioners/Joseph-Mohorovic/Commissioner-Mohorovic-Statement/

Statements/Statement-of-Commissioner-Joseph-P-Mohorovic-Regarding-The-Commissions-

Provisional-Civil-Penalty-Settlement-with-Sunbeam-Products-Inc-DBA-Jarden-Consumer-

Solutions/ (calling for more clarity and transparency in the CPSC's application of penalty factors to reach a civil fine amount).

342. For example, the Consumer Product Safety Act, 15 U.S.C. § 2069(a)(1) (2012), includes a $\$ 15$ million cap on civil penalties "for any related series of violations." Statutes administered by the National Highway Traffic Safety Administration (NHTSA) also include aggregate civil penalty caps "for a related series of violations" or "for a related series of daily violations" ranging from $\$ 1$ million to \$35 million depending on the type of violation at issue. See 49 U.S.C. §§ 30165(a)(1), (a)(2)(B), (a)(3), (a)(4) (2012).

343. There is a long history of use of treble damages as an appropriate level of punishment in UDAP and other laws. See Exxon Shipping Co. v. Baker, 554 U.S. 471, 507 (2008). 


\section{Ensure Settlement Money Furthers Consumer and Taxpayer Interests}

There are several options for addressing the questionable use of money received as a result of UDAP settlements and judgments by state officials. Three main approaches are increasing transparency regarding the use of recovered funds, restricting the AG's discretion in spending or allocating recovered funds, and requiring the AG to turn over the funds to the state legislature.

Some state laws specifically provide that civil penalties, or, more broadly, money recovered from UDAP settlements and judgments must be deposited in the state's general fund. ${ }^{344}$ Once deposited in the general fund, such funds are allocated through the ordinary legislative appropriation process. In order to allow the AG to retain some control over their budget, states wishing to adopt this approach might also consider adding a provision that provides that before depositing the money in the general fund, the AG is authorized to use the recovered funds to reimburse documented, reasonable litigation expenses associated with the UDAP action, including expert witness fees, copying of documents, and transcripts. This approach ensures that taxpayers receive the full benefit of any recovery. Several state legislatures have considered, but not yet enacted, reforms along these lines. ${ }^{345}$

A potentially more politically feasible approach is to establish a consumer protection fund and permit the AG to retain a portion of UDAP settlements and judgments and use them exclusively for the office's consumer education and enforcement activities. In order to limit the AG's control over the recovered funds, some states subject the fund to annual legislative appropriation. ${ }^{346}$ The money in these funds may carry over from one fiscal year to the next. ${ }^{347}$ A few states place a cap on the

344. See, e.g., Fla. Stat. AnN. § 501.2075 (West 2010) (civil penalties); Ky. Rev. StAt. AnN. $\S \S 48.005(2)(a),(4)$ (West Supp. 2013) (funds or assets); VA. CODE ANN. § 59.1-206(C) (West 2011) (civil penalties).

345. See, e.g., LD 1414, 127th Me. Leg., 1st Reg. Sess. (Me. 2015), http://www.mainelegislature.org/legis/bills/display_ps.asp?ld=1414\&PID=1456\&snum=127; H.B. 4799, Reg. Sess. (Mich. 2009), http://www.legislature.mi.gov/(S(zoiu5y3vdvkcpeg4ppfejlmd))/ mileg.aspx?page=getObject\&objectName=2009-HB-4799.

346. See, e.g., ARIZ. Rev. Stat. ANN. § 44-1531.01(A) (2013 \& Supp. 2015); IDAHo Code ANN. § 48-606(5) (West 2006); see also LA. REV. STAT. ANN. § 49:259 (2006) (providing that all proceeds recovered by the AG on behalf of the state, including settlements and civil penalties, must be deposited in a special fund in the state treasury, which is annually appropriated to the Department of Justice solely for certain litigation costs).

347. See, e.g., ARIZ. Rev. StAT. AnN. § 44-1531.01(A) (2013 \& Supp. 2015); Conn. Gen. StAT. ANN. § 21a-8a(a) (West 2006); Del. CodE AnN. tit. 6, § 2527(b) (West 2011 \& Supp. 2016); N.J. STAT. ANN. § 56:8-133 (West 2012). 
maximum balance of the fund, after which any additional funds go to the state's general fund ${ }^{348}$ or divide recovery between the general fund and a consumer protection fund. ${ }^{349}$ New Hampshire adopted this approach in 2015, when it provided that all funds recovered by the AG in a consumer protection action must be deposited in the state's consumer protection escrow account and that any amount over $\$ 5,000,000$ must be deposited into the state's general fund. ${ }^{350}$

This approach may be a good fit in states that already have such a fund in place to assist in financing the AG's consumer protection efforts and ensure that settlement money is not spent on unrelated activities. ${ }^{351}$ By placing a cap on the fund and requiring any excess funds to be deposited into the general fund, the legislature maintains control over most of the recovered funds while providing the AG a limited amount it can use at its discretion. The cap also ensures that taxpayers share the benefit when a state enters in an extraordinary settlement or judgment and that large sums are not withheld from the legislative appropriation.

States have also attempted to address the concern over the use of recovered funds by increasing transparency as to the disposition of UDAP enforcement actions. Arizona and Arkansas, for example, have required the AG to provide a quarterly or annual report to the legislature that includes, for each settlement or judgment, the aggregate recovery, the value of restitution to a state agency or consumers, amounts recovered for civil penalties, amounts recovered for attorney fees, the AG's use or planned use of the amounts received, and the balance of the AG's fund. ${ }^{352}$

Arkansas recently instituted a package of reforms that increased transparency and placed bounds on the AG's allocation of settlement funds. After controversy over the AG's spending of settlement money to build a police training facility in 2011, the office of the Arkansas AG

348. See, e.g., DeL. Code ANN. tit. 6, § 2527(c) (West Supp. 2016) (\$3,000,000 limit in any fiscal year after which the excess is deposited in the General Fund).

349. See, e.g., MIss. CODE ANN. § 75-24-19(1)(b) (West 1999) (AG may receive one-half of civil penalties upon petition to court, payable into AG's special fund).

350. N.H. REV. STAT. ANN. § 7:6-f (Supp. 2015).

351. See, e.g., Ariz. Rev. Stat. AnN. § 44-1531.01 (2013 \& Supp. 2015); Conn. Gen. Stat. ANN. § 21a-8a (West 2006); DeL. CodE ANN. tit. 6, § 2527 (West 2011 \& Supp. 2016); N.J. STAT. ANN. § 56:8-133 (West 2012); OHIO Rev. CodE ANN. § 1345.51 (West 2004 \& Supp. 2014); W. Va. Consumer Protection Recovery Fund (Special Revenue Account, Fund 1509); see also NEV. REV. STAT. ANN. § 598.0975(1)(a) (West 2014) (requiring deposit of recovery into state general fund for use in enforcing consumer protection law).

352. ARK. Code AnN. § 4-88-105(f)(2) (West Supp. 2014); ARIZ. Rev. Stat. AnN. § 441531.01(D) (2013 \& Supp. 2015); see also H.B. 4799, Reg. Sess. (Mich. 2009) (including quarterly report requirement). 
announced a new internal policy on lawsuit settlement funds. ${ }^{353}$ The state legislature codified this reform in 2013. ${ }^{354}$ The statute provides that whenever the state receives a portion of a settlement or judgment from an action to which the state is a party, the AG must distribute the money in the following manner: (1) payment to the Arkansas consumers or state agencies designed by a court order or settlement agreement; (2) payment to a state agency having a nexus to the underlying litigation; (3) payment of attorney's fees to the State Treasury; or (4) payment into the AG's "Consumer Education and Enforcement Account," which is exclusively used for specified consumer litigation and education related expenses. ${ }^{355}$ The Arkansas law also caps the enforcement account at \$1 million and requires the AG to provide quarterly financial reports to the Legislative Council. ${ }^{356}$

In states in which the AG controls recovered funds, legislatures should consider precluding allocation of state recovery from UDAP settlements and judgments to outside organizations. ${ }^{357}$ This step would eliminate the concerns that arise when state AGs and other officials give money recovered as a result of litigation to politically popular projects and handpicked organizations. If an AG is authorized to distribute funds from UDAP settlements and judgments, then, at minimum, he or she should be limited to providing money to state agencies for activities that have a close nexus to the underlying litigation.

\section{CONCLUSION}

The problematic enforcement practices discussed in this Article cut across the states. They are not limited to AGs in any particular political party. These types of actions are becoming more commonplace. Private

353. See Ark. Office of the Att'y Gen., AG Policy on Lawsuit Settlement Funds (Oct. 11, 2011), http://www.thearkansasproject.com/wp-content/uploads/2011/10/0752_001.pdf.

354. 2013 Ark. Acts 763 (H.B. 2083) (amending ARK. CODE ANN. §§ 4-88-105(e) and adding (f)).

355. ARK. Code ANN. § 4-88-105(e)(3)(B), (f)(2) (West Supp. 2014).

356. Id. § 4-88-105(e)(3)(B), (f)(4).

357. The U.S. Department of Justice adopted a policy in 2008 that generally prohibits settlements that require a criminal defendant "to pay funds to a charitable, educational, community, or other organization or individual that is not a victim of the criminal activity or is not providing services to redress the harm caused by the defendant's criminal conduct.” OFFICES OF THE U.S. Attorneys, U.S. Dep’t of Justice, U.S. Attorneys' Manual § 9-16.325 Plea Agreements, Deferred Prosecution Agreements, Non-Prosecution Agreements and "Extraordinary Restitution" (Feb. 2010), https://www.justice.gov/usam/usam-9-16000-pleas-federal-rule-criminal-procedure11\#9-16.325. This policy, however, does not extend to civil settlements. Legislation pending before Congress would preclude the federal government from entering any settlement agreement in a civil action that requires a donation to any party. H.R. 5063, 114th Cong., 2d Sess. (2016). 
law firms that specialize in representing AGs and other government bodies, or that focus on bringing similar private litigation, are emboldened by multi-million dollar recoveries in UDAP actions and identifying new targets. Despite the controversy that can ensue, many AGs appear open to this type of litigation. That is not surprising because, under current law in many states, contracting out law enforcement authority is low-risk and low-cost, can lead to headline grabbing settlements and judgments against unpopular industries, and can result in an influx of funds that AGs can allocate at their discretion.

These types of actions, however, are not what policymakers envisioned when enacting UDAP laws. Rather than protect consumers harmed by deceptive business practices, these outlier enforcement actions primarily benefit the private lawyers who bring them and the AGs who hire those lawyers. Instead of filling gaps where consumer protection is needed, they often target practices already closely regulated by agencies charged with protecting the public. Some simply pile on fines for concerns that regulators considered fully resolved.

AGs can fully protect consumers from unfair or deceptive business practices without sponsoring litigation that seeks unwarranted or excessive civil penalties, interferes with the expertise of agencies that regulate certain areas, or intrudes on the power of legislators to appropriate funds. State legislatures and courts should address overreach. A combination of modest legislative reforms, principled judicial interpretation of UDAP laws, increased transparency, and closer protection of due process rights can keep UDAP enforcement on track. Such measures can ensure that UDAP actions respond to a public need, civil penalties reflect the conduct at issue, and settlement funds serve consumers and the public interest. 